\title{
Modernising the Common Law Offence of Cheating the Public Revenue
}

\author{
Graham McBain ${ }^{1,2}$ \\ ${ }^{1}$ Peterhouse, Cambridge, UK \\ ${ }^{2}$ Harvard Law School, USA \\ Correspondence: Graham McBain, 21 Millmead Terrace, Guildford, Surrey GU2 4AT, UK. E-mail: \\ gsmcbain@aol.com
}

Received: December 22, 2014 Accepted: January 9, 2015 Online Published: February 13, 2015

doi:10.5539/jpl.v8n1p40

URL: http://dx.doi.org/10.5539/jpl.v8n1p40

\section{Introduction}

A previous article ${ }^{1}$ considered the common law offence of misconduct in a public or judicial office. As well as proposing that this offence become a statutory one, the article asserted that the statutory offence should not cover offences by public officers involving the dishonest handling of money. ${ }^{2}$ Rather, it should be restricted to cases of public officers neglecting their duty or exercising oppressive conduct - especially in the legal field. ${ }^{3}$ This purpose of this article is to consider the following common law offence, in the context of its modernisation:

- Cheating the Public Revenue. This offence was a category of the wider common law offence of 'cheating'. Although cheating as an offence was abolished by the Theft Act 1968, there was a saving for cheating the public revenue. ${ }^{4}$

The conclusion to this article in respect of this offence may be stated at the outset. It is asserted that the offence of 'Cheating the Public Revenue' should become a statutory offence - one of 'Defrauding the Public Revenue'. In analysing this offence, regard is had to the following legal texts in particular:

- H Bracton, On the Law and Customs of England (c. 1240); 5

- Britton (c. 1290); ${ }^{6}$

- $\quad$ Fleta (c. 1290); ${ }^{7}$

- $\quad$ Mirror of Justices (c. 1290); ${ }^{8}$

- $\quad$ E Coke, Institutes of the Laws of England (1628-41); ${ }^{9}$

- W Hawkins, A Treatise of the Pleas of the Crown (1716-1824); ${ }^{10}$

- $\quad$ M Hale, The History of the Pleas of the Crown (published 1736, written 1640's); ${ }^{11}$

- W Blackstone, Commentaries on the Laws of England (1765-9); ${ }^{12}$

\footnotetext{
${ }^{1}$ GS McBain, Modernising the common law offence of Misconduct in a Public or Judicial Office.

${ }^{2}$ Ibid. See also 29.

${ }^{3}$ The early caselaw shows that it mainly covered JP's corruptly, arbitrarily, maliciously or partially exercising their discretion.

${ }^{4}$ Theft Act 1968, s 32(1) The following offences are hereby abolished for all purposes not relating to offences committed before the commencement of this Act, that is to say (a) any offence at common law of..., except as regards offences relating to the public revenue, cheating.'

${ }^{5} \mathrm{H}$ Bracton (trans Thorne), On the Law and Customs of England c.1240 (Cambridge UP, 1968-76). Bracton is now online, see bracton.law.harvard.edu

${ }^{6}$ FM Nichols (ed), Britton (John Byrne \& Co, 1901).

${ }^{7}$ Fleta, see Selden Society ('SS'), vols 72, 89 and 99.

${ }^{8}$ Mirror of Justices, SS, vol 7.

${ }^{9}$ E Coke, Institutes of the Laws of England (W Clarke \& Sons, London, last ed, 1824).

${ }^{10}$ W Hawkins, A Treatise on Pleas of the Crown (E \& R Nutt \& R Gosling, Savoy ( $1^{\text {st }}$ ed 1716-21, last ed ( $8^{\text {th }}$ ed), 1824).

${ }^{11}$ M Hale, The History of the Pleas of the Crown (printed for E \& R Nutt \& R Gosling, 1736).

${ }^{12}$ W Blackstone, Commentaries on the Laws of England (Oxford, Clarendon Press, $1^{\text {st }}$ ed, 1765-9, University of Chicago Press rep 1979).
} 
- WO Russell, A Treatise on Crimes and Misdemeanors (1819-1964); ${ }^{13}$

- W Archbold, Criminal Pleading, Evidence and Practice (1822-2014); ${ }^{14}$

- Halsbury, Laws of England. ${ }^{15}$

It may be noted, in respect of this offence, that - apart from Archbold, Halsbury and Blackstone's Criminal Practice $^{16}$ - modern criminal texts contain no (or little) detailed analysis of it. ${ }^{17}$ Reference is also made to various Abridgments, major and minor, viz.

- $\quad$ N Statham, Abridgment of the Law (c. 1490); ${ }^{18}$

- $\quad$ A Fitzherbert, La Graunde Abridgment ( $3^{\text {rd }}$ ed, 1577); $;^{19}$

- $\quad$ R Brooke, La Graunde Abridgment (1586); ${ }^{20}$

- W Hughes, Grand Abridgment of the Law (1660-3); ${ }^{21}$

- W Sheppard, Grand Abridgment of the Common and Statute Law of England (1675); ${ }^{22}$

- H Rolle, Abridgment des plusieurs Cases et Resolutions del Common Ley (1668); ${ }^{23}$

- W Nelson, Abridgment of the Common Law (1725-6); ${ }^{24}$

- E Viner, A General Abridgment of the Law and Equity (1t ed, 1741-57); ${ }^{25}$

- $\quad$ M Bacon, New Abridgment of the Law ( $5^{\text {th }}$ ed, 1798); ${ }^{26}$

- J Comyns, Digest of the Laws of England (last ed, 1822). ${ }^{27}$

In conclusion, this article considers the common law offence of cheating the public revenue. ${ }^{28}$

\section{Cheating the Public Revenue: Present Offence}

Prior to analysing the history of this offence its present incarnation may be referred to. This is best summarised in Archbold (2014). ${ }^{29}$ It states, as to this offence:

\footnotetext{
${ }^{13}$ WO Russell, A Treatise on Crimes and Misdemeanors ( $1^{\text {st }}$ ed, 1819; last ed, 12 ${ }^{\text {th }}$ ed, 1964).

${ }^{14} \mathrm{~W}$ Archbold, Criminal Pleading, Evidence and Practice (Sweet \& Maxwell, 2014). See also JF Archbold, A Summary of the law relative to Pleading and Evidence in Criminal Cases (London, 1822, being the $1^{\text {st }} \mathrm{ed}$ ).

${ }^{15}$ Halsbury, Laws of England (5th ed, with updates).

${ }^{16}$ Blackstone's Criminal Practice 2013 (eds. A Hooper \& D Ormerod)('Blackstone CP'). See also Archbold, Magistrates Courts Criminal Procedure ('Archbold Procedure').

${ }^{17}$ See, for example: (a) C McAlhone \& R Huxley-Binns, Criminal Law. The Fundamentals (3rd ed, 2013); (b) MJ Allen, Textbook on Criminal Law (12 ${ }^{\text {th }}$ ed, 2013); (c) A Ashworth \& J Horder, Principles of Criminal Law ( $7^{\text {th }}$ ed, 2013); (d) R Card et al, Criminal Law (20 $0^{\text {th }}$ ed, 2012); (e) CMV Clarkson \& HM Keating, Criminal Law, Text and Materials ( $7^{\text {th }}$ ed, 2010); (f) C Elliott \& F Quinn, Criminal Law (8 $8^{\text {th }}$ ed, 2010); (g) R Heaton, Criminal Law (2 ${ }^{\text {nd }}$ ed, 2006); (h) J Herring, Criminal Law ( $8^{\text {th }}$ ed 2013); (i) M Jefferson, Criminal Law ( $9^{\text {th }}$ ed, 2009); (j) Lacey, Wells \& Quick, Reconstructing Criminal Law. Text and Materials ( $\left.{ }^{\text {th }} \mathrm{ed}, 2010\right) ;(\mathrm{k}) \mathrm{J}$ Loveless, Complete Criminal Law. Text. Cases and Materials ( $3^{\text {rd }}$ ed, 2012); (1) N Padfield, Criminal Law ( $7^{\text {th }}$ ed, 2010); (m) A Reed \& B Fitzpatrick, Criminal Law (4 ${ }^{\text {th }}$ ed, 2009); (n) AP Simester, Simester $\&$ Sullivan's Criminal Law: Theory and Doctrine ( $5^{\text {th }}$ ed, 2013); (o) D Ormerod, Smith \& Hogan's Criminal Law (13 ${ }^{\text {th }}$ ed, 2011); (p) DJ Baker, Glanville Williams Textbook of Criminal Law ( $3^{\text {rd }}$ ed, 2012); (q) MJ Allen \& S Cooper, Elliott \& Woods' Cases and Materials on Criminal Law (1 $1^{\text {th }}$ ed, 2013); (r) M Molan, Cases and Materials on Criminal Law (4 ${ }^{\text {th }}$ ed, 2008); (s) J Martin \& T Storey, Unlocking Criminal Law ( $3^{\text {rd }}$ ed, 2010); (t) P Hungerford-Welch \& A Taylor, Sourcebook on Criminal Law (1997); (u) M Molan et al, Bloy \& Parry's Principles of Criminal Law ( $4^{\text {th }}$ ed, 2000); (v) W Wilson, Criminal Law $\left(4^{\text {th }}\right.$ ed, 2011). For older $20^{\text {th }}$ century texts, see JW Cecil Turner, Kenny's Outlines of Criminal Law (19 ${ }^{\text {th }}$ ed, 1966) and R Cross \& PA Jones, An Introduction to Criminal Law ( $2^{\text {nd }}$ ed, 1949).

${ }^{18} \mathrm{~N}$ Statham, Abridgment of the Law (Pynson, c. 1490). This has been reprinted by the Law Book Exchange. For a translation, see MC Klingelsmith, Statham's Abridgment of the Law (Boston Book Company, 1915).

${ }^{19}$ A Fitzherbert, La Graunde Abridgment (Tottell, $3^{\text {rd }}$ ed 1577). This has been reprinted by the Law Book Exchange.

${ }^{20} \mathrm{R}$ Brooke, La Graunde Abridgment (Tottell, 1586).

${ }^{21}$ W Hughes, Grand Abridgment of the Law (Henry Twyford et al, 1660-3). This has been reprinted by the Law Book Exchange.

${ }^{22}$ W Sheppard, Grand Abridgment of the Common and Statute Law of England (sold by George Sawbridge et al, 1675).

${ }^{23} \mathrm{H}$ Rolle, Abridgment des plusieurs Cases et Resolutions del Common Ley (A Crooke et al, 1668).

${ }^{24}$ W Nelson, Abridgment of the Common Law (E \& R Gosling, 1725-6). This has been reprinted.

${ }^{25}$ E Viner, A General Abridgment of the Law and Equity (GCJ \& J Robinson, $1^{\text {st }}$ ed, 1741-57, $2^{\text {nd }}$ ed 1791). This has been reprinted by the Law Book Exchange (there is also a CD with wordsearch).

${ }^{26}$ M Bacon, New Abridgment of the Law (H Gwillim (ed), $5^{\text {th }}$ ed, 1798).

${ }^{27}$ J Comyns, Digest of the Laws of England (A Hammond, last ed, 1822). See also J Lilley, Practical Register (2 ${ }^{\text {nd }}$ edn, 1765).

${ }^{28}$ See also D Ormerod, Cheating the Public Revenue [1998] Crim LR 627.

${ }^{29}$ Archbold, n 14, para 25-409.
} 
To make a false statement (whether written or not) relating to income tax with intent to defraud the Revenue, or to deliver or cause to be delivered a false document relating to income tax with similar intent, amounts to a common law offence and is indictable as such: $R v$ Hudson ${ }^{30} \ldots$

Hudson was applied in $R v$ Mavji $^{31}$ in which the Court of Appeal held that a deception is not a necessary ingredient of the offence of cheating the public revenue. Cheating could include any form of fraudulent conduct which resulted in diverting money from the Revenue and depriving the Revenue of money to which it was entitled. In Marvji, the appellant had a statutory duty to make VAT returns and to pay over to the Crown the VAT due: he had done neither. Accordingly, he was guilty of cheating the Crown and the public revenue. No further act or omission was required to be alleged or proved. The court said that, notwithstanding the existence of a statutory offence of fraudulently evading the payment of $\mathrm{VAT}^{32}$ the common law offence may properly be charged for serious and unusual offences rather than conventional cases of value added tax fraud. In such cases, punishment remains at large and the court will not be inhibited by the statutory maximum from upholding what would otherwise be a proper sentence.

Mavji was applied in $R v$ Redford. ${ }^{33}$ The Court of Appeal held that the common law offence of cheating the public revenue was still indictable, even though statutory offences might have been available on the facts, see the Theft Act 1968, s 32(1)...

The offence was satisfied by matters of omission. As Lord Mansfield said in $R v$ Bembridge ${ }^{34}$ 'So long ago as the reign of Edward III [1327-77], it was taken to be clear that an indictment would lie for an omission or concealment of a pecuniary nature, to the prejudice of the king.' Thus, the failure of the appellant to register for VAT and make the requisite returns and payments to the Commissioners of Customs and Excise when due was enough to constitute the offence.

Hudson and Redford were also applied in $R v$ Mulligan ... ${ }^{35}$ citing Hawkins, Pleas of the Crown ${ }^{36}$ that 'all frauds affecting the Crown and the public at large are indictable as cheats at common law.' In $R$ $v$ Hunt ${ }^{37}$ it was held that cheating the Revenue is a 'conduct' offence and there is no requirement to prove resultant loss. (wording divided for ease of reference)

Archbold then considered the forms of indictment and sentencing.

In conclusion, the offence of cheating the public revenue at common law: (a) has been applied to various taxes; (b) deception is not a pre-requisite; (c) the offence can be committed by omission as well as by commission; (d) the offence can be committed even if there also exist statutory offences very similar to it; (e) no loss need be proved. In light of this, the early history of the offence is now considered, not least since all of (a)-(e) apply because this offence is a misprision at common law, something more recent cases in respect of this offence appear to have overlooked.

\section{Early History- Henry I (1100-35)}

An analysis of the early history of this offence is instructive, since it shows how the offence 'evolved' in early law.

\section{(a) Early History}

It is vain to seek the very beginnings of it, like so many common law offences. The following may be noted, however:

- Anglo-Saxon $\mathbf{L a w}^{38}$ This concentrated on relatively few crimes - mainly those concerning personal violence. Save where summary justice was administered, ${ }^{39}$ crimes were usually punished by way of

${ }^{30}$ [1956] 2 QB 252.

31 (1987) 84 Cr App R 34.

32 Value Added Tax Act 1994, s 72(1).

33 (1988) 89 Cr App R 1.

${ }^{34}$ (1783) 22 ST 1 at 155. See also 3 Burr 1317 (97 ER 851).

${ }^{35}$ [1990] Crim LR 427.

$368^{\text {th }}$ ed (ie. 1824 ed), p 322.

${ }^{37}$ [1994] Crim LR 747.

${ }^{38}$ Useful texts comprise: FL Attenborough, The Laws of the Earliest English Kings (NY, 1963); AJ Robertson, The Laws of the Kings of England from Edmund to Henry I (Cambridge UP, 1925) and B Thorpe (ed), Ancient Laws and Institutions of England (1840). See also BR O'Brien, God's Peace and King's Peace. The Laws of Edward the Confessor (Univ. of Pennsylvania Press, 1999). 
fine, with the exception of the most serious crimes. In part, this was likely due to the absence of prisons. ${ }^{40}$ In part, it was also likely due to the fact that the sovereign (and his officials) preferred to receive money rather than impose incarceration. Thus, the criminal legal system comprised - to a considerable extent - a tariff scale of compositions (of fines). ${ }^{41}$ Further, theft tended to be the pre-dominant crime; ${ }^{42}$

- Laws of Henry I (1100-35). This tariff system, as the primary means of punishment for crimes, continued, at least, until the Laws of Henry ${ }^{43}$ (written c. 1113). ${ }^{44}$ This can be seen from the fact that they, also, contain a large number of provisions on fines. Incarceration up this period would, anyway, have been a problem since there were few Crown prisons. In London, for example, until 1197, (probably) the Tower of London was the only royal prison of note. ${ }^{45}$

By the time of Henry I, the Exchequer had become relatively sophisticated. There was also a form of general tax - Danegeld, a tax on land. ${ }^{46}$ As to this:

- Danegeld. The jurisdictional rights over Danegeld were exclusive to the Crown. ${ }^{47}$ Thus, it was not franchised and payment was made directly to the Crown, being usually collected by the sheriffs. ${ }^{48}$ The Laws of Henry I provided that: 'If Danegeld, which was formerly given to the Danish forces, that is, twelve pence from each hide per annum, is not paid at the appointed times, amends shall be made by the payment of the wite.' [a fine payable to the Crown]; ${ }^{49}$

- Court Fees \& Fines. As well as Danegeld, money also came to the Crown as a result of court fees, and amercements. ${ }^{50}$ However, the right to these was sometimes franchised. Thus, the Laws of Henry I

39 Outlaws, for example, could be killed on the spot. So, too, thieves with the mainour, that is, with the stolen goods on them (mainour was spelt in various ways. However, it likely derived from in manu (in the hand)). As to mainour, see GS McBain, The Charters of the Cinque Ports - Are they Still Needed? (2013) Rev. of European Studies, vol 5, no 2, p 117. The position under Roman law was the same. It distinguished between manifest theft and other theft.

${ }^{40}$ F Pollock \& FW Maitland, The History of English Law before the time of Edward I (Cambridge UP, $2^{\text {nd }}$ ed, 1898, rep 1968) ('P \& M'), vol $1, \mathrm{p} 49$ 'Imprisonment occurs in the Anglo-Saxon laws only as a means of temporary security.' See also TFT Plucknett, Edward I and Criminal Law (Cambridge UP, 1960), p 90 'A most striking feature of our older criminal law and legislation is its reluctance to use imprisonment; even when it does appear, it is often merely a means to the end of extracting money from the offender.'

${ }^{41}$ Ibid, p 47 'Full scales of composition are established. A freeman's life has a regular value set upon it, called wergild, literally 'man's price' or 'man-payment', or oftener in English documents wer simply; moreover, for injuries to the person short of death there is an elaborate tariff.' Ibid, p 48 'Wite is the usual word for a penal fine payable to the king or to some other public authority.' Ibid. 'The only punishments, in the proper sense, generally applicable to freemen, were money fines, and death in the extreme cases where redemption with a money fine was not allowed.' Coke, n 9, vol 1, s194, fo 127a, 'wite, wita, is an old Saxon word, and signifieth an amercement.'

${ }^{42}$ Ibid, p 55 'Theft, especially of cattle and horses, appears to have been by far the commonest and most troublesome of offences.'

${ }^{43}$ LJ Downer, Leges Henrici Primi (Oxford, 1972), p 167.

${ }^{44}$ The date of this text is unknown. Pollock \& Maitland, $n$ 40, suggested it was c. 1115 (and that it could not have been written after 1118). Downer, $\mathrm{n} 43$, proposed c. 1113. Further, it should be noted that the 'Laws of Henry' I is not a statement of the 'laws' of Henry I as such. Rather it is (as Pollock and Maitland note, $\mathrm{n} 40$, vol 1, p 101) more of a legal text. That said, the work likely reflected - with a fair degree of accuracy - the law in the author's time. Ibid, vol 2, p 457 'The writer of the Leges Henrici represents the criminal law of his time as being in the main the old law, and we have no reason to doubt the truth of what he tells us.'

${ }^{45}$ William I (1066-87) built the first royal prison, the Tower of London, which was likely used as such from 1100. Other early royal prisons comprised the Fleet prison in London (1197-1814) and the 'baulk house' at Winchester (established between 1103-15). It was not until the Assizes of Clarendon in 1166, that Henry II (1154-89) ordered sheriffs to have prisons built in each county where they did not previously exist, in order to hold those accused of felonies until they could be tried by justices in eyre. Many towns were also ordered by the sovereign to maintain prisons. See generally, GS McBain, Modernising the Law of Escape, Prison Breach and Rescue.

${ }^{46}$ Danegeld (gild, geld) was a tax on 2 shillings of every hide of land. It was first imposed under Ethelred II (978-1016) in 991, to raise money for tribute exacted by the Danes. In effect, it was a levy for national defence (a war tax). Danegeld was revived by William I (1066-87) in consequence of a possible Danish invasion. After 1163, danegeld dropped out of use, being superceded by donum or hidage (hydage), itself superceded in 1194 by Richard I (1899-99) as carucage. A tax on all holders of land of whatever tenure, carucage was levied on every plough (or caruca). Carucage was, itself, replaced in 1224, effectively by tallage. See generally, McBain, n 39, pp 99-102.

${ }^{47}$ Downer, n 43, p 109 'These are the jurisdictional rights which the king of England has in his land solely and over all men, reserved through a proper ordering of peace and security...Danegeld... These are the crown pleas of the king; they do not belong to the sheriffs or his officials or bailiffs in their farms except by definite arrangement beforehand.'

${ }^{48}$ See R Fitzneale, The Ancient Dialogue concerning the Exchequer (London, 1758), p 27 (the sheriffs were 'free from it in regard to their domains, by reason of their labour in collecting the revenue.').

${ }^{49}$ Ibid, p 121.

${ }^{50}$ As the Laws of Henry I noted, some pleas of the Crown could not be compensated for by money (such as arson, manifest theft, palpable murder, treachery to one's lord etc). Others could, by payment of 100s or wergild or wite. See $\mathrm{p} 115$. The monetary payment increased if the offence was re-committed, viz. 'He who violates the law shall forfeit his wergild on the first occasion; if he does it a second time he shall pay twice his wergild; if he ventures to do it a third time, he shall lose all he possesses.' Ibid, p 117. 
noted that: 'In the case of the soke of pleas, some of these profits belong peculiarly and exclusively to the royal treasury, some are shared by it with others, some belong to the sheriffs and royal officials in their farm, and some belong to the lords who have soke and sake. '; 51

- Tax Collectors - Sheriffs \& Bailiffs. In the time of Henry I, tax collection was effected by sheriffs and their bailiffs. The former often paid a 'farm' (ferm $)^{52}$ to the sovereign, giving them a right to collect taxes (or other duties and rents) owed to the sovereign. Sometimes, whole shires were farmed. While this was very useful to the Exchequer - since they only had to deal with one person - it was an open invitation to sheriffs (and their bailiffs) to practice extortion and other forms of fraud, extracting as much as they could from the payees, to enable the sheriffs to pay their farm as well as to make a hefty profit. It was, likely for this reason, the citizens of London acquired from Henry I by a charter c. 1131/2, the right to pay the farm for the City of London and Middlesex, as well as to appoint their own sheriff. ${ }^{53}$ It is also likely that 'tax farming' derived from Roman law. Then, farmers were called 'publicans' and they were, similarly, rapacious; $;^{54}$

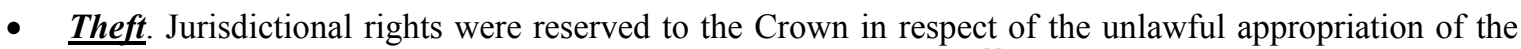
king's land or money (presumptio terre vel peccunie regis). ${ }^{55}$ This is not unexpected. it is not something a sovereign would generally want to franchise. Further, under the Laws of Henry I, concealment of the king's own chattels was equivalent to theft. ${ }^{56}$

\section{(b) Punishments}

As to punishments for appropriating (that is, stealing or failing to pay) the sovereign's revenue, the following may be noted:

- Appropriating Sovereign's Revenue. The Laws of Henry I do not make crystal clear what was the punishment when a person (especially the sheriff who was primarily liable for tax collection) cheated the Exchequer. For example, appropriating sums due to the sovereign. However, since 'unlawful appropriation' of the king's money was a matter for the jurisdiction of the Crown and - since 'concealment of the king's own chattels' was treated as theft - any dishonest appropriation of the sovereign's money would almost certainly have been held to be theft. ${ }^{57}$ It is also clear - from the Laws of Henry I - that theft was a generic crime of wide scope; ${ }^{58}$

\footnotetext{
${ }^{51}$ Ibid. 'Sake and soke' (there are a number of variant spellings) probably comprised a Crown grant of judicial jurisdiction, including the right to hold a court and the profits arising therefrom (ie. the collection of fines and amercements for various criminal offences). See Fleta, $\mathrm{n}$ 7, vol 72, $\mathrm{p}$ 101. See generally, McBain, n 39, pp 106-7. See also Rv The Dean and Chapter of St Martin-Le-Grand in the Year Books of Edward II, The Eyre of London 14 Edward II, AD 1321, SS, vol 86, p 296 per Stanton J 'Soke means (the right) to hold a court for their tenants; sake means the right to have in that court the amends of trespasses.'

${ }^{52}$ A rent collector or farmer (firmarius or fermor) bought the right to collect rents and/or taxes on behalf of the sovereign. This, in return for a fixed rent or farm (firma comitatus), which was usually annual, which he paid to the Exchequer, for the sovereign. The word derived from the Anglo-Saxon 'foerme' (farm). See generally, GS McBain, Liberties and Customs of the City of London - Are there any Left? (2013) Int. Law Research, vol 2, no 1, p 6. See also Irish Exchequer Reports, SS, vol 125, pp lxix-xx. See also FS Thomas, The Ancient Exchequer of England (London, John Petheram,1848), p 49 'The sheriffs were the chief agents for bringing in the Revenue and a great part of the land revenue went through their hands: they were the king's bailiffs of their respective counties. The other accountants were the escheators, foresters, the farmers or custodes of such towns and burghs as were not part of the corpus comitatus, nor within the sheriff's receipt, the custodes cambia, the customers, the keepers of the wardrobe and others. And in succeeding times, the collectors of tallages, dismes, aids, etc...All accountants rendered their accounts at the Exchequer in a somewhat similar manner to the sheriffs...'

${ }^{53}$ The charter (the original was in latin) provided that: 'I have granted to my citizens of London, to hold Middlesex to farm for [£300], upon accompt to them and their heirs; so that the said citizens shall place a sheriff [vicecomitem] whom they will of themselves'. In fact, two sheriffs were appointed (for the City and Middlesex), although they were treated as one.' See McBain, n 52, p 6.

${ }^{54}$ A particular praetorian Edict governed farmers collecting tax (tribute) by force, see A Watson, The Digest of Justinian (Univ. of Pennsylvania Press, 1985), vol 3, p 403 (D.39.4). If the farmer took anything by force in the name of the public revenue (or they took wrongfully or by theft) the fine was double the sum involved. The jurist Ulpian noted that 'Tax farmers are those who enjoy the use of public money (whence the name publicani), whether they pay vectigal [tax] to the treasury or collect tribute.' Ibid. D 39.4.1.

${ }^{55}$ Downer, n 43, p 109 'These are the jurisdictional rights which the king of England has in his land solely and over all men, reserved through a proper ordering of peace and security... unlawful appropriation of the king's land or money.'

${ }^{56} \mathrm{Ibid}, \mathrm{p} 117$, 'Concealment of the king's own chattels is equivalent to theft' (dominica capitalia regis celata pro furto habeantur). See also $\mathrm{P}$ \& M, n 40, vol 2, p 499.

${ }^{57}$ Up to the time of Henry I (1100-35), payments to the Crown were not usually in money but in specie (such as food, drink, animals etc). If any of these allocated to the Crown were mis-appropriated, this would be theft. Thus, there is no reason to believe that money payments to the Crown (often, such payments comprised objects of gold and silver until coinage became more common in the reign of Henry I) would have been treated differently. See T Madox, The History and Antiquities of Exchequer of the Kings of England (2 ${ }^{\text {nd }}$ ed, 1769) republished by
} 
- $\quad$ Punishment - Theft. As to the punishment for theft, the Laws provided that a person who committed theft forfeited his land. ${ }^{59}$ Further, some forms of theft could be compensated, others could not. ${ }^{60}$ Thus, manifest theft (also called, 'open theft' or 'hand having theft') ${ }^{61}$ could not be compensated and, indeed, summary punishment was often administered in respect of it. ${ }^{62}$ More particularly, theft punishable with death was a matter for the royal courts. ${ }^{63}$ In the case of appropriating the sovereign's revenue (such as underpaying, or stealing, taxes or court fees), this was not manifest theft. Therefore, payment of a wite (fine) would apply;

- Likelihood of Appropriating Sovereign's Revenue. In the case of sheriffs (and their assistants), one would suspect that they did not seek to appropriate the sovereign's revenues often, since there were easier ways for a sheriff to make money. If a sheriff appropriated such money, he would incur (at least) a heavy fine, forfeiture of land and (probably) loss of a lucrative office. ${ }^{64}$ Thus, common sense suggests that a sheriff 'on the make' was more likely to pay the Exchequer the sums they calculated he owed, and then practice extortion using the power of his office. This helps explain why sheriffs achieved a level of infamy - resulting in a progressive diminution of their tax gathering and judicial powers after Magna Carta 1215. ${ }^{65}$ As for the payment of tax, a failure to pay Danegeld resulted in payment of a wite (fine)(see above). Since Danegeld was an oppressive tax in any case, payment of an additional fine would be even more.

In conclusion, it is asserted that a person appropriating the sovereign's revenue in the time of Henry I (1100-35) would be punished for theft - the same as if that person had stolen the sovereign's chattels. 'Appropriating' would mean any dishonest failure to pay Danegeld or other monies owed to the Crown.

\section{Early History- From Henry I - Edward I (1272-1307)}

The first legal text, Glanvill's Treatise on the Laws and Customs of the Realm (c. 1189) ${ }^{66}$ did not deal with crimes relating to the revenue.

\section{(a) Exchequer ${ }^{67}$}

The text - Dialogue concerning the Exchequer (Dialogus de Scaccario) ${ }^{68}$ - which is thought to have been written c. 1189 by (possibly) Richard Fitznigel (also called Richard Fitzneal, c. 1130-98) is useful since he was the

Greenwood Press, NY 1969, ch 9 (of the species wherein the ancient Crown revenue was usually paid). See also Fitzneale, n 48, p 20 and Thomas, n 52, p 25.

${ }^{58}$ Basically, there was theft and robbery (ie. theft with force), the law on theft not having yet separated into a large number of common law (and, later, statutory) sub-divisions. The position under early Roman law was the same.

${ }^{59}$ Downer, $\mathrm{n}$ 43, p 153 'Anyone who commits a theft...shall forfeit his land.'

${ }^{60}$ Ibid, p 189 'Every theft, whether of livestock or other chattels, whether of one thing or of several, may be amended by making compensation or may not; of the ones which may be compensated for, some are satisfied by the loss of a limb, others by the payment of money.'

${ }^{61}$ For a description of manifest theft, see Bracton, n 5, vol 2, p 425.

${ }^{62}$ Thus, persons caught by hue and cry with stolen property on them, were usually executed on the spot. Ibid, p 115 'Some pleas cannot be compensated for with money... manifest theft.' By 1290, the dividing line for theft punishable with death or not was if the sum exceeded $12 \mathrm{~d}$ (about 8 days wages for a labourer at the time), see Britton, $n$ 6, p 47. Manifest theft was still capital in the $13^{\text {th }}$ century. P \& M, n 40, vol 2, p 496 'In the thirteenth century manifest grand larceny was a capital crime...'.

${ }^{63}$ Downer, $\mathrm{n}$ 43, p 109 'Jurisdictional rights which the king of England had in his own land solely and over all men' included 'theft punishable by death'. Also, p 117 'Pleas which place a man in the king's mercy... manifest theft punishable by death (furtum probatum et morte dignum).

${ }^{64}$ Misconduct by a public official was also a very old offence at common law, see $\mathrm{n} 1$.

${ }^{65}$ See generally, GSMcBain, Abolishing Obsolete Offices (2012) Coventry LJ, vol 17, pp 31-60. Magna Carta (1215) began the process of reducing the sheriff's powers generally. Chapter 24 provided that: 'no sheriff, constable, coroners, or others of our bailiffs, shall hold pleas of our Crown.' and chapter 42 (1297 version) provided that no sheriff or bailiff was to make his tourn more often that twice a year. WS McKechnie, Magna Carta (Glasgow, John Maclehose \& Sons, 1914), p 305 'The sheriffs and castellans deserved their bad repute: the records of the age overflow with tales of their cruelties and oppressions.' At p 311 'No royal officer was more justly hated than the sheriff.' 42 Edw III (1368), s 9 provided that no sheriff or under sheriff or sheriff's clerk could hold office for more than a year. See also J Reeves, History of the English Law (Dublin, $2^{\text {nd }}$ ed, 1787), vol 3, p 281.

${ }^{66} \mathrm{R}$ Glanvill (trans G Hall), Treatise on the Laws and Customs of the Realm (Nelson, 1965). Glanvill made it clear that he was only dealing with the king's court and not the sheriff's court etc. Ibid, p 177. And, in Glanvill's time, theft did not belong to the Crown pleas but to the sheriff. Ibid, pp 3-4, 'Pleas are either criminal or civil. Some criminal pleas belong to the crown of the lord king, and some to the sheriffs of counties...The crime of theft...belongs to the sheriffs, and is pleaded and determined in the counties.'

${ }^{67}$ See Madox, n 57. See also Thomas, n 52. For some remarks on the Exchequer in the $16^{\text {th }}$ century, T Smith, De Republica Anglorum (1562-3)(ed M Dewar, Cambridge UP, 1982), pp 96-9.

${ }^{68}$ See $\mathrm{n} 48$. 
king's treasurer for some forty years. ${ }^{69}$ Further, Fitznigel was the nephew of Roger, Bishop of Salisbury who organised the Exchequer under Henry I when it was separated from the chamberlain's office in the king's household. Therefore, the description of the Exchequer in this work likely reflects the Exchequer in the time of Henry I (1100-35) ${ }^{70}$ as further altered under Henry II (1154- 89).

- Exchequer. What seems clear both from this work - and that of Madox ${ }^{71}$ - is that the Exchequer (which kept the Crown's accounts) was well organised in both the reigns of Henry I and II. And, that sums owed to the Crown were rigorously enforced. Indeed, the system was carefully designed to prevent any form of tax or revenue evasion;

- Appearance in Person. Thus, the Dialogue noted that any debtor - or a sheriff to whom debts were farmed - had to appear in person at the Exchequer twice a year (usually at Easter and Michaelmas), after being summoned. ${ }^{72}$ The summons itemized what they owed (their 'account' or accompte) ${ }^{73}$

- $\quad$ Attorney. Such persons (the 'accountant') had to appear in person. If this was not possible they had to have the Crown's permission to appoint an attorney. Even if an attorney was appointed, a person still remained primarily liable. Further, at least, by 1275 a system of 'totting' was in place; ${ }^{74}$

- $\quad$ Sheriff. When the accountant (including a sheriff) appeared at the Exchequer he was required to hand over what was owed. In the case of the sheriff, he had to pay the ferm, regardless of whether his debtors had paid or not. Further, unpaid ferm was 'carried over';'

- $\quad$ Oath. An accountant also had to give an oath in public 'that he has made a just accompt according to his conscience. ${ }^{, 75}$ If he remained indebted in any way it was added to the oath that he would not depart without leave of the Barons of the Exchequer, ${ }^{76}$

- $\quad$ Failure to Attend. If a debtor failed to attend the Exchequer when summoned without lawful excuse (which excuses was very restricted), he was fined a huge sum daily ${ }^{77}$ for 'you would by this means have appeared to have despised the king's command, and to have acted indecently against the king's majesty. ${ }^{78}$

- $\quad$ Failure to Pay. If a debtor failed to pay the Exchequer the sum owed according to the summons, their estates and goods could be distrained to meet the debt (levy being made by the sheriff). ${ }^{79}$ Also, he could be apprehended and delivered to the king's marshall who could send him (if the marshall thought

\footnotetext{
${ }^{69} \mathrm{P} \& \mathrm{M}, \mathrm{n}$ 40, vol 1, pp 161-2.

${ }^{70}$ Prior to Henry I, there was an exchequer. However, it is likely to have been more rudimentary in nature. Further, prior to Henry I payments to it tended to be in specie (ie. in food and animals) as opposed to in coin, see $\mathrm{n} 57$.

${ }^{71}$ See $\mathrm{n} 57$

${ }^{72}$ Fitzneale, n 48, p 36 cited a summons in his time (c.1189) 'Henry, king of England to such or such a sheriff greeting. See as you love yourself, and all yours, that you be at the exchequer at such or such a place, on the morrow of St Michael, or on the morrow of the close of Easter, and have there with you whatever you owe of old or new ferme, and the names of the debts subscribed, ten marks of such an one for such a cause, and so on.'

${ }^{73}$ As Fitzneale, n 48, p 38 pointed out, it would do no good for a debtor or sheriff to strike out debts referred to in the summons since they were also entered on the rolls 'so that no one, not even with the sheriff's assistance, can be discharged from his debt by this contrivance.'

${ }^{74}$ The Statute of Westminster I (1275) introduced an o.ni system (an abbreviation of the latin, oneratur nisi habeat sufficientem exonerationem - he is charged, or legally responsible, unless he have a sufficient discharge). Thus, once a debtor to the sovereign paid the sheriff, the debtor was discharged of liability and the sheriff was liable instead; he was 'oni.d', that is, liable until he discharged the debt by paying the money owed into the Exchequer. From 1368, when the debtor paid the sheriff, the latter marked ('totted') the amount in his record and the debtor was discharged. The sheriff was then required to pay the money into the Exchequer or to pay treble damages. See n 52, vol 125, pp 1xiii-iv.

${ }^{75}$ Madox, n 57, p182 'Accounts were to be rendered at the Exchequer upon oath. When the accountant had been sworn de fideli compoto reddendo, he entered upon and went through his account.'

${ }^{76}$ Fitzneale, n 48, p 10 'It also belongs to this officer [the sheriff] ... to give him [the king's marshall] an oath in public, that he has made a just accompt according to his conscience. But if the sheriff, or he who accomps, is any ways [ie. still] indebted, he adds to the oath, that he will not depart without leave of the barons from the exchequer, that is, from the space of ground in which it is situated, but that he will return the same day.' Madox, n 57, p 243 'If accountants departed from the Exchequer, before their accounts were speeded, or without leave of the barons, they were (if commoners) to be attached by their bodies.'

${ }^{77}$ Fitzneale, $\mathrm{n} 48, \mathrm{p} 39$ said that the fine was 100 shillings of silver the first day for every county and 10 pounds of silver the next. And, for 'the third, one hundred in like manner, as I have been told by my predecessors whatever movables he is in possession of shall be at the king's disposal, but the fourth, because now he has proved his contempt of the royal majesty, not only his estate, but also his person shall be subject to the royal mercy.'

${ }^{78}$ Ibid, p 39.

${ }^{79}$ Ibid, pp 50-1 A failure to pay an Exchequer debt was 'offending against the royal majesty'. Ibid, p 53.
} 
proper) to a public prison. ${ }^{80}$ Finally, a debtor could only be discharged of sums owed when he was discharged by the Exchequer.

The basic premise in these times - and thereafter - was stated by Madox:

If an accountant did not come to render his account, or did not pursue the same in due manner, he was punished several ways: namely, by distress and seizure of his lands, and by amercement. If he did not answer to the Crown the debts or sums wherewith he was charged, he was committed either to the Marshall, or to the Fleet Prison, or to the Tower of London... If debtors did not keep their terms or days of attermination, ${ }^{81}$ they were amerced; and sometimes by neglecting to make a second or third payment, forfeited or lost the sum which they had actually paid in for their first payment. ${ }^{82}$

Finally, sums owed to the Exchequer (the king's debt) was always to be paid first. ${ }^{83}$ As to the basis on which the Exchequer operated:

- Structure of the Exchequer. Madox argued that the structure of the Exchequer (royal treasury) in England derived from that brought over from Normandy by William I (1066-87). ${ }^{84}$ From the English Exchequer developed the Irish Exchequer, post $1210{ }^{85}$ Both Exchequers were divided into two parts the Inferior Exchequer (also called the receipt of the Exchequer) and the Superior Exchequer (the Court of Exchequer). ${ }^{86}$ The former comprised the administrative department concerned with the receipt of royal revenue and other debts due to the sovereign. The latter was concerned with disputes as to the royal revenue and debtors of the sovereign; ${ }^{87}$

- Exchequer Revenues. Money accruing to the sovereign via his Exchequer - apart from sums voted by Parliament - took the form of hereditary revenue and casual revenue;

- Hereditary \& Casual Revenue. Hereditary revenue mainly comprised: ${ }^{88}$ (a) Crown rents and reliefs; ${ }^{89}$ (b) Customs and excise duties (including prisage on wine and other prises); ${ }^{90}$ (c) seizures and forfeitures (including escheat). ${ }^{91}$ Casual revenue mainly comprised: treasure trove, fines, forfeited recognizances, waif, wreck, chattels of felons and fugitives, chattels of outlaws, usurers, recreants, persons executed etc. ${ }^{92}$

As to defrauding the Exchequer, this was considered Bracton.

\footnotetext{
${ }^{80}$ Ibid.

${ }^{81}$ Madox, n 57,vol 2, p 208 'By attermination is meant, granting men several terms or days for payment of their debt, where they were not able, or could not conveniently pay it at one entire payment.'

${ }^{82}$ Ibid, pp 234-5. Of the office of Marshall of the Exchequer, see p 284. See also 13 Edw 1 (1285), s 11 (indebted accountants might be put in prison).

${ }^{83}$ Ibid, pp 176-89 (the king could also betake himself for payment to one indebted to his debtor). Further, the king's debtors were to find sureties for payment, if required. Ibid, p 197.

${ }^{84}$ Madox, n 57, vol 1, p 262 'Exchequer, was at first a general name, signifying as well the place where the king's revenue was supervised and managed as that where it was wont to be paid in. In the early times, that part of the Exchequer, where the king's treasure was told, reposited, or issued, was usually called the thesaurus.' See also Coke, $\mathrm{n}$ 9, vol 4, pp 131-2 and Thomas, n 52, pp 1, 23-4.

${ }^{85}$ See $\mathrm{n}$ 52, vol 125.

${ }^{86}$ This had been established by 1189 . See Fitzneale, n 48, p 4.

${ }^{87}$ See $\mathrm{n} 52$, p lix.

${ }^{88}$ Madox, $\mathrm{n}$ 57, vol 1, ch 10 listed as the notable parts (or branches) of the Crown revenue: (a) demesne: (b) escheats; (c) vacant bishoprics and monasteries; (d) feudal and other profits arising out of the king's demesnes and escheats, viz. reliefs, wardships, marriages; (e) yearly ferms of counties and of towns or burghs or gilds; (f) fines and amerciaments; (g) aids, scutages, tallages and customs; (h) casual revenue (treasure trove, waif, wreck, chattels of felons and fugitives, chattels of outlaws, usurers, recreants, persons executed etc). Those in italics are now obsolete. Further, the Royal demesne is now part of the Crown Estate (since 1760). Court fines and amerciaments still exist as a source of revenue. See also Thomas, $n$ 52, pp 32-44. Hereditary revenue has been commuted (at the beginning of the sovereign's reign) for a fixed Civil List since 1760.Thus, it is paid into the national Exchequer.

${ }^{89}$ Reliefs were an incident of tenure. They comprised, in feudal law, the sum a tenant's heir had to pay in order to succeed to his ancestor's property. The payment (which became fixed at one year's additional rent) was made in recognition of the lord's seignory. See DM Walker, The Oxford Companion to Law (Oxford, 1980), (definition of reliefs). For reliefs in the time of Henry I (1100-35), see Downer, n 43, p 119.

${ }^{90}$ Madox, n 57, vol 1, ch 18 (Madox noted prisage on wine (also called prisa and recta prisa), duties on merchandise (often, the duty was a tenth (disme) or fifteenth (quinzime) of their value) and tronage (weighing of goods etc, see ns 176-7).

${ }^{91}$ Escheat comprised land which reverted to the lord if: (a) a tenant died without heirs (escheat propter defectum sanguinis); or (b) if a tenant committed a gross breach of the feudal bond, such as to the Crown in the case of high treason (escheat propter delictum tenentis). Both forms of escheat have been abolished with (a) being replaced by bona vacantia. See generally, Walker, n 89 (definition of escheat).

92 See eg. Madox, n 57, p lx.
} 


\section{(b) Bracton: Defrauding the Exchequer}

Bracton, in his On the Law and Customs of England (c. 1240), ${ }^{93}$ considered the nature of theft (furtum), defining it as follows:

Theft, according to the laws, is the fraudulent [fraudulenta] mishandling of another's property without the owner's consent, with the intention of stealing, for without the animus furandi it is not committed. ${ }^{94}$

As Maitland and Pollock noted, essential to this offence was 'taking and carrying away'. ${ }^{95}$ Thus, theft readily covered the stealing of chattels such as beasts and goods etc.

- However, theft did not as easily cover the case of one person defrauding another, where the latter willingly handed over their money or possessions, but as a result of a trick. Nor, in the case of the revenue, where (for example) a sheriff dishonestly failed to pay over tax or other sums he had collected;

- As a result, it is unsurprising that there developed over the course of time - as also happened with Roman law $^{96}$ - specific offences covering fraud, bribery, extortion, exaction and other deceits. However, this was at a later date. ${ }^{97}$ In 1240, it seems clear that justices in eyre were still employing the generic offence of theft to cover these offences.

When Bracton considered the matters which justices of eyre were required to inquire into, sheriffs and their bailiffs featured high on the list as malefactors. ${ }^{98}$ Thus, Bracton referred to:

- Courts - sheriffs (and bailiffs) who summoned people to courts they convened and who then took amercements for not answering the summons or for not raising the hue and cry or not pursuing it. ${ }^{99}$ Also, sheriffs (and other bailiffs) who fromented litigation; ${ }^{100}$

- Bribes \& Ransoms - sheriffs (and bailiffs) who took bribes ${ }^{101}$ or ransomed people; ${ }^{102}$

\footnotetext{
${ }^{93}$ See $\mathrm{n} 5$.

${ }^{94}$ Bracton, n 5, vol 2, p 425 'Et sciendum quod furtum est secundum leges contrectatio rei alienae fraudulenta cum animo furandi, invito illo cuius res illa fuerit.' P \& M, n 40, vol 1, p 56 'The common law of theft is wholly post-Norman.'

${ }^{95} \mathrm{P} \& \mathrm{M}, \mathrm{n}$ 40, vol 1, p 498 'The crime involves a violation of possession; it is an offence against a possessor and therefore can never be committed against a possessor.' E Griew, The Theft Acts $1968 \& 1978$ (Sweet \& Maxwell, $6^{\text {th }}$ ed, 1990), p 12 'Historically, larceny was an offence against another's possession of goods; and it involved a violation of that possession by 'taking and carrying away' his goods without his consent, with the intention of permanently depriving him of them. Such a 'taking' could not occur where there was a consensual delivery; nor could it occur where the offender was himself already in possession, for instance as a bailee. But one who induced a delivery by fraud was regarded as 'taking' without consent because the fraud was treated as negativing the victim's apparent consent; and a bailee became capable of larceny (by conversion of the goods bailed) by a statutory extension of the offence. The element of 'carrying away' (or 'asportation') required some physical removal of the goods, however slight.'

${ }^{96}$ AM Prichard, Leage's Roman Private Law ( ${ }^{\text {rd }}$ ed, 1961), p 400 'it seems that there was much controversy throughout Republican and classical jurisprudence as to what constituted theft...A cause of the confusion was the comparatively late development of the praetorian edict of dolus, late enough to have tempted the early jurists to incorporate in theft cases more of fraud and false pretences - eg. employing false weights to cheat a vendor.'

${ }^{97}$ Cf. JC Smith, The Law of Theft (6 $6^{\text {th }}$ ed, 1989), Preface, 'Theft has come a long way since the law of larceny required 'asportation', a physical taking of property out of the possession of the owner and a carrying away.'

${ }^{98}$ Introduction to the Curia Regis Rolls, SS, vol 62, p 419 'Few offices were more desired in the middle ages than the shrievalty, and no official was more frequently called to book for his misdeeds in the records of the period, sometimes in very round terms, than the sheriff.'

${ }^{99}$ Bracton, n 5, vol 2, p 330-1. (a) 'sheriffs and other bailiffs of the lord king who held pleas of the Crown... and [of those] who convene the hundred or wapentake courts in order to inquire as to homicide or other pleas of the Crown, [and then] take amercements for not answering the summons or for not raising the hue or for not pursuing it.' (b) 'sheriffs and other bailiffs who hold and determine pleas of the Crown and of replevin... in county or hundred courts, though they have no jurisdiction therein without the special mandate of the lord king and by his writ.'

${ }^{100}$ Ibid. (a) 'of the excesses of sheriffs and other bailiffs, whether they have fromented litigation for the purpose of acquiring lands or wardships or of obtaining money or other profits by which justice and truth are stifled or suffer delay.'

${ }^{101}$ Ibid, (a) 'of bribes taken for ensuring that corn and other goods shall not be seized for munitioning castles.' (b) 'of bailiffs who have taken gifts or bribes from removing recognitors from juries and assizes; also of sheriffs and bailiffs who have taken ransoms from squires holding a whole knight's fee or having twenty pounds worth of land, that they not be made knights at the king's command, though the sheriffs and other bailiffs have not had special instructions thereon from the king about making such as are of full age knights.' (c) 'of sheriffs and other ambidextrous bailiffs who take bribes from both sides.' (d) 'of sheriffs and other bailiffs who have taken bribes from those accused of homicide for releasing them on bail though they should not be replevied without the special order of the lord king.'

${ }^{102}$ Ibid. (a) 'of sheriffs and other bailiffs who have imprisoned those accused of theft by indictments or an approver's appeal and have kept them in prison until they could obtain ransom from them, though they may and ought to be allowed bail by the law of the land without any ransom, or if they took ransom from such men that they not be imprisoned.'
} 


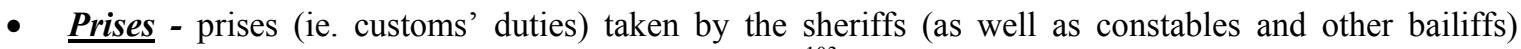
without the consent of those who owned the chattels; ${ }^{103}$

- $\quad$ Amercements - sheriffs and bailiffs who levied amercements twice over. ${ }^{104}$

Bracton also specifically referred to revenue matters which affected the Exchequer:

- Distraint 'Of sheriffs and other bailiffs who have distrained anyone to pay more than the sum at which he was amerced by summons of the exchequer;',105

- Prises. 'Of the king's prises... and how much they are worth a year, and who has taken them or concealed them or withheld them. ${ }^{106}$

'Prises' referred to goods which were dutiable, such as the prisage of wine (recta prisa) which was a customary charge on imported wine (it was abolished in 1809). ${ }^{107}$ There were also other prises imposed in early times on a range of other goods such as: wool, corn, oats, malt, hides, oxen, cattle, salt, meat etc. ${ }^{108}$

It seems clear, when Bracton wrote (c 1240), that it was an offence to defraud the Exchequer and that defrauding the Exchquer included non-payment of any tax, customs as well of other hereditary and casual revenues.

\section{Early History- Edward I (1272-1307)}

\section{(a) Britton - Inquiry of Justices at Eyre}

When Britton (c.1290) came to discuss the frauds of sheriffs and their bailiffs which should be inquired into by justices in eyre, the list was longer than that of Bracton. ${ }^{109}$ The deteriorating situation may be explained.

- The reign of Edward I (1272-1307) was characterised by the fact that he was frequently at war - with the Scots and the French. The sovereign was also frequently away from England, providing an opportunity for his officials to become corrupt - something which many of them did.

In his list of things to be inquired of by the justices at eyre, Britton stipulated these included:

our escheators and under escheators... of all their receipts to our use and their own use, how much they have taken for endowing widows, or for suffering them to be endowed, or for permitting heirs being infants to continue with their mothers; and also for making insufficient extents of land, or for certifying our wardships and our marriages to be less than their real value, or for concealing anything which ought to turn to our profit;

or for procuring or suffering false inquests to pass upon the ages of our wards, or in any other thing, to our prejudice; and let such presentments as shall be made concerning these officers be enrolled and transmitted to the exchequer, and there determined. We reserve however the judgments upon great

\footnotetext{
${ }^{103}$ Ibid. (a) 'prises taken by the sheriff, constable or other bailiffs without the consent of those who owned the said chattels.'

${ }^{104}$ Ibid. (a) 'of sheriffs and other bailiffs who have twice or several times taken money from someone, as though he had been amerced several times when he had been amerced only once.' (b) 'of sheriffs and other bailiffs who have distrained several men bearing the same name for several amercements when one only had been amerced.'

${ }^{105}$ Ibid, p 332.

${ }^{106}$ Ibid. See also 3 Hen 6 (1425) c 3 (customs officers concealing customs to forfeit treble value).

${ }^{107}$ Blackstone, n 12, vol 1, p 304 'Prisage was the right of taking two tons of wine from every ship importing into England twenty tons or more, which by Edward I [1272-1307] was exchanged into a duty of 2s for every ton imported by merchant strangers; which is called butlerage, because it is paid to the king's butler.' See also 16 Edw 2 (1323). See also GS McBain, Modernising the Monarchy - in Legal Terms, (2010) King's LJ 21 (3), p 544 and McBain, n 39, p 104. The Cinque Ports obtained an exemption from this in 1278 and the City of London in 1327, see Ibid, p 104.

${ }^{108}$ Ibid. For the position in respect of prises by 1297 in the reign of Edward I which produced widespread discontent, see TFT Plucknett, Taswell-Langmead's English Constitutional History (1 $\left.1^{\text {th }} \mathrm{ed}, 1960\right)$, p 147.

${ }^{109}$ Britton, n 6, pp 71-2. See also the Statutes of the Exchequer (Les Estatuz del Eschekere)(which were likely made in the early years of Edward I (1272-1307)), Statutes of the Realm (1714) ('SR', now on CD, see Tanner Ritchie Publishing), vol 1, pp 197-8, art 1 ('The king commandeth, that all manner of bailiffs, sheriffs, and other officers, as well as the [Justices] of Chester, and [other bailiffs of these counties] as other, [that be receivers] of wards, of escheats, [and other] bailiwicks, shall be answerable in the Exchequer, and there shall make account to the Treasurer and Barons of the same place.' Ibid, art 2 ('And that all sheriffs, fermors, bailiffs of franchises, and other, [shall come] to the profer in the Exchequer, the Monday after the utas of Easter for to pay their ferms, rents and issues belonging to the king, and shall bring at the aforesaid terms, the foresaid ferms, rents, and issues [due] wholly into the Exchequer [as before is mentioned]. And if [they make default their bodies], shall remain without departing from there, until [they] have paid or made agreement: And he that will not come to the terms aforesaid, shall be amerced after the [custom] of the Exchequer: And the sheriffs and bailiffs at the same terms shall bring and pay such money as they have received of the summons of the Exchequer, and other the king's debts: and shall be prepared and ready to make [full account] of the things aforesaid.' See also art 15 (punishment of officers of the Exchequer for misconduct).
} 
offences committed by them to our own determination. ${ }^{110}$

This reference to escheators is useful since:

- It refers to revenue offences, their 'concealing anything which ought to turn to our profit';

- Legal complaints (presentments) about the mis-conduct of sheriffs etc were to be submitted to the Exchequer - although 'We reserve ...judgments upon great offences committed by them to our own determnination'. The latter is a precursor to High Crimes and Misdemeanours (see 7).

Britton also referred to inquiry being made of frauds committed by coroners ${ }^{111}$ as well as of sheriffs (and their bailiffs) viz. ${ }^{112}$

- Concealing Felonies etc. 'sheriffs and other officers, who for reward or entreaty or out of friendship for any man may have concealed felonies committed in their balliwicks, or suffered remain unapprehended, whether within their franchises or without, or have let to mainprise prisoners who were not bailable, and have detained others who were bailable; ${ }^{113}$

- $\quad \underline{F e r m s}$. 'sheriffs who have knowingly let their hundreds ${ }^{114}$ to farm to persons of no substance at too high a rent, to the wrongful oppression of the people in divers manners; and let such be amerced;'

- Amercements. 'sheriffs and bailiffs who have levied money of the chattels of felons, or for the escape of prisoners, or from amercements for defaults made before coroners or escheators or other general inquirers, or for non-prosecution in appeals of felony, or from mainpernors who failed in producing the persons delivered to them on writs of menace, or for not pursuing the hue and cry raised, or for treasure or wreck of the sea, or sturgeon or whale found or carried away, which amercements no man ought to levy without our writs of green wax by estreats of our exchequer; and let such offenders be punished by fine.' 115

- Juries \& Inquests. "sheriffs or bailiffs, who have summoned more people upon juries and inquests than were necessary, with intent to oppress some of them and take bribes from others for leave to stay at home, or to remove some from the panel and put others thereon;, ${ }^{116}$

- Justices. 'justices, sheriffs, hundredors, and others who have courts, and of the stewards and bailiffs of the same, who through malice have procured suits to be stirred up against any to oppress them, or have caused writs of right to be brought wrongfully in their court, in order to

\footnotetext{
${ }^{110}$ Ibid. See also 42 Edw III (1368), s 9. It indicated that many escheats were levied by sheriffs in deceit ('deceit') of the king. Thus, a sheriff who failed to levy any estreat properly (ie. under the seal of the Exchequer) was punished with triple damages to the person estreated and also a fine to the king.

111 Ibid. 'the fees taken and frauds committed by coroners, their clerks, and officers, according to that which is contained in our Statutes of Exeter.' For the Statutes of Exeter (Les Estatuz de Excestre) (c. 1286, rep 1863) which deal with Inquests against a coroner 'how he hath borne himself in his office' see SR, n 109, vol 1, p 210 (now on CD, see Tanner Ritchie Publishing).

112 Britton, n 6, pp 71-80.

${ }^{113}$ Ibid. See also, re approvers, 'sheriffs, their clerks and officers, who have falsely and maliciously made [ap]provers appeal innocent people, or hindered them from appealing the guilty; and let such as are guilty of this offence be imprisoned during our pleasure.' It may be noted that in the time of Edward I [1272-1307], clerks received no salary for their services and the principal source of their income was received from fees. See $\mathrm{n} 52$, vol 125, p lxxv. For cases of clerks making fraudulent entries in plea rolls, see Ibid, p lxxxvii, fn 1.

${ }^{114}$ From Anglo-Saxon times, ten tythings made a 'hundred' (or wapentake). It was an administrative (and judicial) unit and part of the overall division of the kingdom into shires (counties), presided over by a sheriff (shire reeve) who was responsible to an earl, himself responsible to the sovereign.

115 Ibid. 'sheriffs, who have taken fines and amercements from persons in their bailiwick, that they might not be distrained to become knights, in which case are amerciable; or that they have maintained suits or the parties to actions, and have procured false inquests, whereby justice has been hindered, in which case they shall be punished by fine; or that have levied one amercement twice, or of two persons bearing the same name, or have levied more than was contained in the estreats of our exchequer; or if any sheriff has procured the removal of any coroner by obtaining our writs upon false suggestions, in which case they are amerciable; or if any sheriff through malice has kept any man in prison whom he ought to have brought before our justices at our goal delivery, and in this case they are to be punished by fine and imprisonment.' See also: (a) Statute of Fines, 27 Edw I (1299), s 2 'let sheriffs beware under pain of great forfeiture, that from henceforth they do make tallies of all such money as they or their officers have received by our commandment.'. See also Thomas, n 52, p 5; (b) 14 Edw 2 (1320)(concerning acquittances by sheriffs), (c) Statute concerning Sheriffs and their Clerks (c 1298), see SR, n 109, vol 1, p 213 ('before the treasurer and barons of the king's exchequer, and elsewhere in the courts of the king himself before any of his justices, as well as the clerks as the sheriffs themselves shall answer for false return, and be punished).

${ }^{116}$ Ibid. Also, 'sheriffs who have held their tourn oftener than twice a year; and of their hundreders and others, who have held their views of frankpledge oftener than twice a year; also concerning sheriffs who have answered to us less than they ought for issues forfeited, in which case they are amerciable in double the value of the profit they have made.'
} 
increase their courts and the amercements of it; or have amerced people according to their own assessing, or in any other manner than by their peers, beyond the proportion of their offence, contrary to the ordinance of the Great Charter [ie. Magna Carta]. And of all wrongful payments taken by our officers of traverse or of toll...in which case they are amerciable in double the amount of the damages. But as to trespasses of Justices we will that no judgment shall be given without our order;'

- $\underline{\boldsymbol{R} \text { ecords}}$. 'those who have remitted, or who have caused to be put out of the roll, or have omitted inserting in the roll, fines and amercements belonging to us; let such be ransomed and from thenceforth removed from the court, and their superiors punished at will.'

The justices were also to enquire into customs and excise matters:

Prisage. 'of wines sold, whereof the tuns did not contain two hundred and forty gallons, and who those are who thus sold them by wholesale; and also of the prisage of wines, how many tuns have been taken to our use since the last eyre, and by whose hands, and whether those wines have been sold to any other than ourselves without our orders; and let this article also be determined at our Exchequer;'

Other Prises. 'all sorts of flesh and fish, and of every kind of spice, wax, silk, canvas, cloth, and avoirdupois, ${ }^{117}$ and of all manner of prises, which have been taken to our use since the last eyre, and of the value of each prise. And let inquiry be made concerning our customs of leather and wool, who have collected them, and how many sacks of wool the collectors have permitted to pass without paying custom and how much the yearly value of every kind of custom belonging to us amounts to; and let these articles likewise be determined at our Exchequer, according to the discretion of the treasurer and barons.'

This list of ítems is most useful since it covers - to a greater extent than Bracton did, fifty years earlier - more means by which the Exchequer was being defauded, as well as the punishments.

- In some cases the punishment was by way of fine. In other cases the person would also lose office. And in some cases express reference was made to the Exchequer, leaving it to determine the punishment; ${ }^{118}$

- $\quad$ Further, it should be noted that matters to be inquired of also covered customs and excise. ${ }^{119}$

Finally, as can be seen, there was a tendency in Britton to 'lump together' offences such as bribery, embezzlement, theft, fraud etc. This is not suprising since they were treated as different aspects of theft something also reflected in a work of the same date to Britton - being the Mirror of Justices.

\section{(b) Mirror of Justices}

In the Mirror of Justices (c. 1290), ${ }^{120}$ the author noted that:

Larceny is committed sometimes by open thieves, ${ }^{121}$ and sometimes by tricksters, as is the case in many kinds of merchandise, and is the case with labourers who steal their labours, and with bailiffs, receivers

\footnotetext{
${ }^{117}$ Britton noted, n 6, p 80 that the word 'avoirdupois' was said to have been applied to all goods sold by weight. See also See also Statutes of the Exchequer, n 109, p 178, art 10 (collectors of customs and wool to make yearly account 'of all parcels received in any of the ports, [or other places of] the realm, so that they shall answer for every ship where it was charged, and how much it carried, [and whose the wools were, and for every other charge] in the ship, whereof custom is due, and for the whole receipt.).'

${ }^{118}$ Fleta (c. 1290), n 7, vol 72, p 132 noted that the Exchequer table 'is the place for investigating the fees, rights and franchises belonging to the king. And when there appear in court the sheriffs, escheators, bailiffs and other royal ministers, it is lawful for the barons to hear and determine the plaints of those who are aggrieved either by personal civil wrongs or by false judgements on their part.'

119 As to general taxation, danegeld was supplanted by hydage and carucage. Then, the latter was effectively replaced by tallage (which was supplanted by 1312) and by scutage (which was supplanted by 1315). The main system of taxation then became tenths and fifteenths which were temporary aids levied on personal property. Tenths were said to have been introduced under Henry II (1154-89), the first being the Saladin tithe (tenth) of 1188 . The sums for tenths and fifteenth were made certain in 1335 when, by virtue of the king's commission, new taxations were made of every township, borough and city. The system of tenths and fifteenths was replaced by a land tax in 1670 . See generally, McBain, n 39, pp 102-3.

${ }^{120}$ As to the Exchequer in his time (c. 1290) the author of the Mirror of Justices, p 36, noted 'The Exchequer is a square place which is established solely for the king's profit, where two knights and two clerks, or two literate men, are assigned to hear and determine wrongs done to the king and his crown in respect of his fees and franchises, and also the accounts of his bailiffs and the receivers of the king's revenues and administrators of his goods, under the supervision of a chief who is treasurer of England. The two knights are commonly called barons for the purpose of affeering [ie. assessing] the amerciaments of earls, barons, and of those holding counties and baronies, so that no one may be affeered save by his peers. To this place was assigned a seal and a keeper to make acquittance for every payment to anyone who wished to have it, and to seal writs and the estreats under green wax which issue from this place for the king's profit.'
} 
and administrators of other persons' goods, who steal in rendering account (qi emblent en rendaunt acounte). ${ }^{122}$

The author further noted that, 'into the sin of larceny', fall, inter alia, those:

- who take wrongful, or outrageous, toll in the market;

- who steal by false measures and weights;

- who amerce any out of their own heads (ie. without legal justification);

- officers of the Exchequer and others who deny receipts under the Exchequer seal to anyone for the amount he has paid, and who more than once require payment of a debt;

- $\quad$ sheriffs, bailiffs and other royal officers who unlawfully by extortion take money from the people;

- officers who more than twice a year hold sheriff's courts, or more than once a year hold view of frankpledge in one and the same court, and those who, under unlawful articles, amerce the people. ${ }^{123}$

In conclusion, in 1290, it is clear that there were many means by which the Exchequer was being defrauded by officials such as escheators, coroners, sheriffs and their bailiffs. These various frauds were punished under the generic concept of theft, (large) fines often being payable.

\section{Caselaw $-14^{\text {th }}$ Century}

\section{(a) Caselaw}

The Selden Society reports reveal some cases of defrauding the public revenue or assertions of the same. For example.

- $\quad$ Hugh of Waltham (1321). In the Eyre of London of 1321, Hugh of Waltham, clerk, was indicted of conspiracy with others on the grounds that he had two men in each of the wards of the City, from their own commune and guild, so that every taxation and tallage in London should be assessed by their ordering: 'and whoever they wished to elevate or to oppress might be tallaged by them accordingly, keeping the third penny of every collection for themselves; and this in all the tallages ${ }^{124}$ levied in the time of the king who now is [Edward II, 1307-27], to the common loss of the king and of the whole City. ${ }^{125}$ Hugh was acquitted; ${ }^{126}$

- John of Langton (1342). John of Langton, clerk, late chamberlain of the Exchequer caused a fine to be levied 'in deceit of the king's court and to the disherison of' a women whom it was falsely asserted sought the fine. Brought before the sheriff, the jurors found him guilty of the aforesaid deceit and falsity (de decepcione et falsitate). 'Therefore John is committed to prison in the custody of the sheriff." 127

\section{(b) Meaning of Words}

When reference to the offence of cheating the revenue, the Anglo-Norman word usually employed was 'deceit' or 'deceite' (there are variant spellings). In respect of the word, the following may be noted:

- The word 'deceite' in early times was the same as the word for fraud ${ }^{128}$ (or a cheat); ${ }^{129}$

- While the word 'deceite' was similar to a 'pretence' ${ }^{130}$ and it often involved deception, it was not synonymous with deception - just as fraud was (and is) not the same as deception. Fraud includes deception - but it is a wider term than deception and it need not involve deception; ${ }^{131}$

\footnotetext{
${ }^{121}$ See $\mathrm{n}$ 62. Roman law made the same distinction, see Digest, $\mathrm{n}$ 54, vol 4, p 251 (D.47.2.2) quoting Gaius, Edict, Bk 13 'Theft is of two kinds: either it is manifest or it is not manifest.'

${ }^{122}$ Mirror of Justices, $\mathrm{n} 8$, pp 25-6.

${ }^{123}$ Ibid, pp 26-7 (a note states that the articles referred to are the 'capitula' of the view of frankpledge).

${ }^{124}$ Tallage was both a specific tax on the Royal demesne and used as a general reference to any tax. See McBain, n 39, p 101.

${ }^{125}$ A footnote indicates that the Eyre Roll stated that, when they raised $£ 200$ for the king, they collected $£ 300$ 'from the middling folk' and kept $£ 100$ from themselves.

${ }^{126} R v$ Waltham. The Eyre of London 14 Edward II AD 1321, SS, vol 85, p 49.

${ }_{127}$ Select Cases in the Court of King's Bench (Easter 1357), SS, vol 82, p 22. See also Select Cases in the Exchequer Chamber, SS, vol 51, p 162. The Case of Richard Quatermaynes (1458)(a sheriff, he was amerced for making a false return. He pleaded a pardon). Danvers JCP noted that his default (making a false return) was a misprision, at $\mathrm{p} 166$.

${ }^{128}$ See Oxford English Dictionary ('OED') (fraud), n 119, '1. Trans. To defraud, cheat, or deceive (a person).' 'Of fraud. 1. The quality or disposition of being deceitful, faithlessness, insincerity. 2a. Criminal deception: the using of false representations to obtain an unjust advantage or to injure the rights or interests of another.' Also, 'Fraudsman'. A cheat or rouge.'

${ }^{129}$ See 9.
} 
- One would assert that all of 'deceite' (Anglo-Norman), 'fraude (Anglo-Norman), 132 and 'cheat' (16 century romany cant) are translations of the latin 'dolus malus'. As Lewis and Short note, originally, 'dolus' connoted a 'device, artifice, hence evil intent, wrongdoing with a view to the consequences. ${ }^{133}$ And especially in juridical language, 'dolus malus', was a standing expression for 'guile, fraud, deceit.' 134 Thus, the essence of this offence was (and has always been) fraud. And, implicit in fraud, was (and is) a dishonest intention (dolus malus); ${ }^{135}$

- Finally, it may be noted that the modern words 'deceit' and 'deception' have a different (changed) meaning to the position centuries ago. Then, deceit ('decepcione' in the Anglo-Norman) was much more a reference to fraud and did not imply a positive act of deceiving another. ${ }^{136}$ Today, 'deceit ${ }^{137}$ and 'deception' imply a positive act of misleading in some sense.

\section{Early History of the Offence - High Crimes}

In Bembridge (1783), Mansfield CJ noted that cheating the public revenue could be traced back to, at least, the reign of Edward III (1327-77). Also, that it included omission as well as acts of commission. ${ }^{138}$

- In this article it has been argued that cheating the public revenue can be traced back to before Edward III. Indeed, at least, to the Laws of Henry I (c. 1113)(see 3);

- However, in the case where the cheating was undertaken by important persons an additional means of prosecution started to come into play. Prosecution in Parliament.

Evidence of this can be seen in the reign of Edward II (1307-27). Further, it likely occurred because - in the case of Gaveston (1307) - the sovereign himself was involved (Gaveston being a favourite). Thus, attempts to prosecute him in the Exchequer or by judicial means would likely have been thwarted. ${ }^{139}$ The device employed was to charge a person with High Crimes and Misdemeanours before Parliament.

- To an extent this was presaged by the reference in Britton in 1290 that, in the case of escheators, 'We reserve ...judgments upon great offences committed by them to our own determnination'.(see 5(a)). Thus, cheating the revenue was - in important instances concerning 'great men' - not to be dealt with by the Exchequer but otherwise by the Crown;

\footnotetext{
${ }^{130} \mathrm{OED}, \mathrm{n} 128$, (pretence) 'sense of ' $3 \mathrm{~b}$. A false, feigned, or hypocritical profession or pretension. 4. 'A profession of purpose; especially a false profession, a merely feigned aim or object, a pretext, a cloak.' As can be seen with reference to a later Act of 1541 (see 9), the word was closely associated with something that was false or counterfeit.

${ }^{131}$ This is important in the case of this offence. To fail to supply tax information may not deceive (or mislead) any particular tax official. However, it still robs the fisc. Similarly, no fraudulent representation to any particular tax official is required. The offence is, essentially, one of contempt of the sovereign (eg ns 77-9) and it is committed by the conduct, not the precise mechanism employed.

${ }^{132}$ Anglo-Norman Dictionary (fraude, has vaiant spellings) 'Fraud, deception'. Faire Fraude. 'To deceive, trick.' See anglo-norman. net.co

${ }^{133}$ Lewis \& Short. A Latin Dictionary (OUP, rep 1993). As well as the offence of: (a) theft, Roman criminal law had the offences of (b) swindling (stellionatus) and (c) the Lex Julia on the Embezzlement of Public Money (it dealt with peculatus, that is, the misappropriation of public money or property by theft, embezzlement, or any other means). All of (a)-(c) required a dishonest intention. The English common law crime of defrauding the public revenue (the Exchequer) was developed in a fashion similar to the Roman concept of peculation. Thus, it also required a dishonest intent (dolus malus). Further, it was regarded as a type of fraud. Thus, it was different to other forms of cheat such as: (a) cheating the general public; or (b) cheating a private individual which forms developed under English law in a fashion similar to the Roman offence of swindling (stellionatus)).

134 Ibid.

${ }^{135}$ It should be noted that 'dolus' could refer to intent (ie. dishonestly) as well as a Praetorian delict. Prichard, n 96, p 420 'Dolus as a distinct delict must not be confused with dolus as a ground of liability in certain delicts, where it means willful intent, as in the action on iniuria.' Ibid, p 419 'Dolus. This consisted in wilful conduct in the nature of fraud or trickery with a view to deriving some unfair advantage over another.'

136 The OED, n 128, notes this older sense, (deceit) '1.To ensnare; to take unawares by craft or guile; to overcome, overreach, or get the better of by trickery; to beguile or betray into mischief or sin, to mislead (obs).'

${ }^{137} \mathrm{OED}, \mathrm{n} 128$ (deceit)(in sense 2) '2. To cause to believe what is false; to mislead as to a matter of fact, lead into error, impose upon, delude, 'take in.'

${ }^{138}$ See 13.

${ }^{139}$ Edward II developed disastrous friendships with Piers Gaveston (1284-1312) as well as, later, with the Hugh Despencer, both father and son (the elder, 1261-1326, the younger, 1286-1326). The result was a reign torn apart with Edward II's struggles against barons led by his cousin, the Earl of Lancaster (who was executed for treason in 1322) and then against his own wife and her lover, Roger Mortimer, Earl of March (1287-1330) whom Edward III (1327-77) had executed for treason early in his reign. See generally, Oxford Dictionary of National Biography ('ODNB')) and (the many) biographies on these persons.
} 
- Further, at least since the Laws of Henry I, c. 1113, the general principle was that persons could only be judged by their peers. ${ }^{140}$

One of the first cases of 'High Crimes and Misdemeanours' comprised proceedings against Piers Gaveston in 1307. It was ordained in Parliament and confirmed by the king:

by the examination of prelates, earls, barons, knights, and other good people of the realm, it was found that Piers de Gaveston had evilly counselled the king, and had inticed him to do ill in divers manners; [these are then listed and included that] he cheated the king of his treasure, and sent it beyond sea... ${ }^{141}$ (italics supplied)

In the case of Mortimer (1330), accused in Parliament of high treason, two of the articles exhibited against him declared:

$6^{\text {th }}$. The said Roger, by his usurped royal power, caused the king to give to him and his children, and confederates, castles, towns, manors, and franchises in England, Ireland, and Wales, in decrease of the revenues of the crown...

$10^{\text {th }}$ The said Roger by his said usurped royal power, had caused to be taken from him [ie. Edward II, 1307-27] and his party, the king's treasure, as much as he pleased, without tale, in money and jewels, in destruction of the king, so that he had not wherewithal to pay for his victuals. ${ }^{142}$ (italics supplied)

These cases are of 'High Crimes and Misdemeanours' (though they are not impeachments as such since they arose by way of accusation by the Crown - as opposed to accusation by the House of Commons followed by judgment by the House of Lords). ${ }^{143}$ Other examples of High Crimes and Misdemeanours involving powerful men defrauding the revenue occurred at the end of the reign of Edward III (1327-77). ${ }^{144}$ The following may be noted (they comprise cases of impeachment by the Commons and judgment by the Lords):

- Lyons (1376). ${ }^{145}$ _A London merchant, Lyons was a member of the privy council as well as a London alderman and a collector (farmer) of customs and subsidies since 1373. He was accused of 'deceits, extortions and other evil deeds' (disceites, extorsions et autres malx faits). Among other things he was impeached and accused (empeschez et accusez) of: (a) imposing and appropriating customs duties without the consent of Parliament; ${ }^{146}$ (b) charging usurious levels of interest on loans to the Crown, including $50 \%$ on a loan of 20,000 marks to Edward III; ${ }^{147}$ (c) buying up royal debts cheaply but obtaining full payment of them at the Exchequer. Found guilty, Lyons was imprisoned at the king's pleasure, his goods were forfeited and he was dismissed from his offices. Lyons was subsequently pardoned but never restored to office, ${ }^{148}$

- William Latimer (1376). ${ }^{149} 4^{\text {th }}$ Baron Latimer, Chamberlain to Edward III. A member of the privy council he was impeached, among others things: (a) with Lyons (above), in causing new impositions to

\footnotetext{
${ }^{140}$ Downer, $\mathrm{n} 43, \mathrm{p} 135$ 'No one of high status shall be condemned by the judgement of lesser men.' Also 'No one shall sit in judgement on him whose liege man he is, even if the case concerns the king.'

${ }^{141} 1$ ST 22. For this, Gaveston was exiled. Later, returning to England, he was seized by barons who were his enemies and executed. See ODNB, n 139. See also JS Hamilton, Piers Gaveston, Earl of Cornwall; 1307-12 (Prentice Hall, 1988).

1421 ST 52 at p 53. Mortimer was executed as a traitor. However, judgment against him was later reversed in Parliament on the basis that he was condemned without a hearing. Ibid, p 54. See also Reeves, n 65, vol 3, pp 142-3.

${ }^{143}$ This is how 'impeachment' tended to be interpreted in later times, see GS McBain, Abolishing High Crimes and Misdemeanours etc. (2011) 85 Australian Law Journal, p 818, n 65. See also p 815, n 36 (re Mortimer).

${ }^{144}$ At the end of his reign, Edward III was much under the (malign) influence of Alice Perrers, his mistress. See McBain, n 143, p 821. For a useful note on Perrers, see EW Brayley \& J Britton, The History of the Ancient Palace and Late Houses of Parliament at Westminster (London, 1836), pp 233-9.

${ }^{145}$ See generally, McBain, n 143, p 821. See also Calendar of Letter-books of the City of London, Letter-Book H(1375-1399), Introduction, pp 2-3.

${ }^{146}$ Rolls of Parliament ('RP'), vol ii 323 'he has set and procured to be set certain new impositions on wool, woolfells and other merchandises, without the assent of Parliament, and levied and collected a great part of these impositions to his own use and to the use of those who are of his said faction close to the king, without the examination or testimony of any controller and without him being charged by record or otherwise except at his will, so that he is the sole treasurer and receiver, and the high treasurer of the realm has no authority over this.' Lyons maintained that the imposition on wool was at the command of the king, which Edward III denied. See The Parliament Rolls of Medieval England (Scholarly Digital Editions, which is also on CD).

${ }^{147}$ There was also an allegation that the loan comprised some of the sovereign's own money.

${ }^{148}$ Lyons may have been pardoned through the influence of Alice Perrers, the mistress of Edward III, see n 144. However, it may have also been through the influence of John of Gaunt, Duke of Lancaster, the third son of Edward III.

${ }^{149}$ See McBain, n 143, pp 822-3.
} 
be imposed on wool etc, contrary to the laws of the realm; and (b) with Lyons, arranging for loans to the king at usurious interest rates. He was fined 20,000 marks, imprisoned and he lost his position in the king's household and privy council. He was later pardoned and restored to favour by October 1376. His crimes were, generally, described as 'deceits, extortions, grievances and other evil deeds' (disceites, extorsions, grevances et autres malx faitz).

Of these, and other cases in that period, ${ }^{150}$ Sir James Fitzjames Stephen said 'All of these were charged with different kinds of fraud and malpractices connected with the revenue. ${ }^{151}$ One would agree. Other early case is that of:

- John Lord Nevill (1376) ${ }^{152}$ Lord of Raby, Steward of the Royal Household, he was impeached, among other things, for: (a) purchasing royal debts (being exchequer tallies) owed to others at a fraction of their worth but obtaining full payment of them at the exchequer; (b) receiving payment in a greater sum than due for taking men-at-arms and archers to Brittany, France in $1372 .{ }^{153}$ Found guilty, he was sentenced by the House of Lords to be removed from his offices and from the privy council, as well as being fined 8000 marks. In 1377, all penalties against him were set aside by Edward III.

Subsequent cases of High Crimes and Misdemeanours of Michael de la Pole (1386), ${ }^{154}$ Sir William Penn $(1668)^{155}$ and Lord Melville (1806) ${ }^{156}$ comprise cases of important people seeking to defraud the public revenue in some way. However, a case noted by Coke, indicated that it could be a dangerous thing to falsely accuse a public officer of mis-using public money:

In 39 E [ie. 1364] Ralph Brantingham one of the chamberlains of the exchequer complained before the king and his council of Richard Cesterfield clerk deputy of the king's treasurer, in the receipt for divers allowances, payments etc unduly made, and for raising [erasing] of records etc. Upon hearing of the cause by the whole council, the defendant was acquitted, and the plaintiff removed from his office, and committed to prison. ${ }^{157}$

In conclusion, from, at least, 1307, defrauding the Exchequer was being punished in Parliament, in the case of great men, as a High Crime and Misdemeanour.

\section{Early History of the Offence - Other Deceits}

As will be seen (see 11), from the time of Hawkins - who wrote the first edition of his Treatise on the Pleas of the Crown in 1716-21 - cheating the revenue has been mixed up with a large number of other 'cheats' (deceits).

- The reason, one would suggest, is that Hawkins 'packaged' them all together, something he had a tendency to do with other offences. ${ }^{158}$ This was a pity since Hawkins rather confused the issue. ${ }^{159}$ The

\footnotetext{
${ }^{150}$ Ibid, p 822, case of Adam Bury. He was charged with appropriating money subscribed for the ransom of the French king, John II (1319-64). His crimes were described as 'deceits' and 'evil deeds.'

151 JF Stephen, A History of the Criminal Law of England (1883), vol 1, p 149.

${ }^{152}$ McBain, n 143, p 825.

${ }^{153}$ This is almost the same as a case in 1353 , see $\mathrm{n} 241$.

${ }^{154} \mathrm{He}$ was impeached, among other things, for: (a) purchasing lands and other sources of royal income contrary to his oath and through their being under-valued; (b) obtaining royal confirmation of a purchase from a Hanseatic trader of a royal annuity which that trader had forfeited (in effect, the accusation was that Pole deceived the sovereign into allowing him an income to which he was not entitled, resulting in loss to the Crown); (c) procuring the revenue of a hospital which should have been taken by the Crown (the accusation was that the hospital revenue was for the sovereign, yet Pole had acquired a personal benefit at the loss to the Crown). See McBain, n 143, p 826.

${ }^{155} \mathrm{He}$ was impeached for high crimes and misdemeanours for embezzling prize goods by breaking bulk, before the captured ships in question had returned to a British port and were adjudged lawful prize, in accordance with Admiralty rules. No further proceedings were taken against him. See McBain, n 143, p 826.

${ }^{156}$ He was impeached for mis-appropriating money in the period 1792-1800 when he was Treasurer of the Admiralty. After trial, he was acquitted. His is the last case of impeachment. See McBain, $n$ 143, p 826.

${ }^{157}$ Coke, $\mathrm{n}$ 9, vol 4, p 60 (falsehood in an officer and raising of a record). Ralph de Brantingham was a chamberlain to the king from 1349-65.

${ }^{158}$ Other instances are the law on: (a) contempt of the sovereign; and (b) misconduct in a public or judicial office, both of which Hawkins also 'packaged'.

${ }^{159}$ How this likely came about is also understandable. Roman law had an offence of swindling. However, it had a separate offence of defrauding the public revenue under the Lex Julia (see n 133). The former was as Prichard noted, n 96, p 32 'a vague crime, a catch-all for the dishonest, comparable with the delict of dolus; [the jurist] Paul described stellionatus as a means of persuading someone to hand his property over to another...in the criminal field stellionatus could be charged wherever there was fraudulent dealing which, nevertheless, did not fall within any other crime, such as forgery or theft.' See also Digest, n 54, vol 4, p 305( D 47.20.3)(the jurist Ulpian, 'this charge can be levelled against those guilty of fraud but against whom no specific offence can be alleged' and 'if he be guilty of some imposture or collusion to another's detriment, he can be charged with swindling.').
} 
other 'cheats' which he referred to, comprised cheats on the general public in some way (breaches of the assizes of bread or beer etc). They were not the same as cheating the Crown, in terms of defrauding it of revenue. Further, the punishment was different. In the case of the former, the punishment was invariably the pillory. In the case of the latter it was never the pillory. Rather, it was fines (sometimes imprisonment as well), loss of land and loss of office;

- This 'packaging' of Hawkins, however, was to be adopted by other legal writers such as in Russell's $O n$ Crimes and Misdemeanours, the first edition of which was in 1819 and the last in 1964. This 'packaging' only ended when the common law offence of cheating was abolished in the Theft Act 1968, with a saving for cheating the revenue (see 1);

- Further, it should be noted that Hawkins - in the case of defrauding the public revenue - never referred to early law such as the Laws of Henry I. Nor to the practice of the Exchequer or the writings of Bracton, Britton, Fleta etc. Nor to High Crimes and Misdemeanours. Instead, Hawkins found the offence of defrauding the revenue virtually on the case of Treeve (1796) (see 14(b)). This also was unfortunate since - although the party defrauded in this case was the Crown - this offence - one of selling unwholesome (ie. rotten) food to the general public - was quite distinct from that of defrauding the revenue.

However, given the policy of Hawkins and its adoption by subsequent writers - and in order to understand how it came about and how 'cheating the revenue' was 'packaged' with other cheats - the early law on these other matters is now considered. The source (as may be expected) are the customs of the City of London - where the Mayor and Alderman developed a system of ordinances to prevent the public from being swindled in the case of basic necessities such as food, drink and clothing and where the 'mysteries' (trades, guilds) helped enforce these. First, as to the source material:

\section{(a) City of London - Cheating - Sources}

The City of London (the 'City') provides some of the earliest, and most common, examples of what Hawkins was, later (in 1716-21), to categorise as public 'cheats'. In respect of the City, the following relevant texts may be noted:

- Letters of the City of London. ${ }^{160}$ These comprise a series of folio volumes in manuscript on parchment. They contain entries of the current matters of the day in which the City was concerned. Published in 11 volumes, being Letterbooks A to I and then $\mathrm{K}$ to $\mathrm{L},{ }^{161}$ they contain a wealth of detail on early frauds and deceits, punished by the Mayor and the alderman of the City at the Guildhall;

- $\quad \underline{\text { Rilev }}$. In a useful text, Memorials of London and London Life...AD 1276-1419, ${ }^{162}$ Thomas Riley, a Victorian researcher, extracted material from the Letterbooks referred to above. Riley's text is referred to for the purposes of this article since it is sufficiently detailed to explain the nature of the 'deceits' (cheats) discussed without also citing the relevant passages in the Letterbooks;

- Liber Albus. In 1419, John Capenter made a repertory (that is, a book of remembrances) of the then existing laws, observances, rights and franchises of the City, which is generally referred to as the Liber Albus (White Book). This was translated by Riley in $1861 ;^{163}$

- $\quad$ Liber Custumarum (Book of Customs) and Liber Horn. ${ }^{164}$ These two texts contained customs of London;

- Calendar of Pleas and Memoranda Rolls of the City. Abstracts, or summaries, from the same have been published in six volumes from 1323-1482; $;^{165}$

\footnotetext{
${ }^{160}$ The full title is 'Calendar of Letter-Books preserved among the Archives of the Corporation of the City of London at the Guildhall' (printed by order of the Corporation under the Direction of the Library Committee).

${ }^{161}$ See Letterbooks A (1275-98), B (1275-1312), C (1291-1309), D (1309-14), E (1314-37), F (1337-52), G (1352-74), H (1375-99), I (1400-22), K (temp Henry VI (ie. 1422-71), L (Edward IV to Henry VII (ie. 1461-1509).

${ }^{162}$ HT Riley, Memorials of London and London Life AD 1276-1419 (Longman, 1868).

${ }^{163}$ Liber Albus: The White Book of the City of London (Richard Griffin \& Co, 1861).

${ }^{164}$ The Liber Custumarum (compiled in the early part of the $14^{\text {th }}$ century) and the Liber Horn (also called Liber Legum Regum Antiquorum) belonged to Andrew Horn, lawyer and City Chamberlain who died in 1328. See HT Riley, Munimenta Gildhallae Londoniensis: Liber Albus, Liber Custumarum et Liber Horn (Longmans, 1860), vol 2, pts 1 \& 2 (see introduction for an explanation of these texts).

${ }^{165}$ Calendar of Pleas and Memoranda Rolls preserved among the archives of the Corporation of the City of London at the Guildhall. Volume 1 (1323-64), volume 2 (1364-81), volume 3 (1381-1412), volume 4 (1413-37), volume 5 (1437-57), volume 6 (1458-82).
} 
- Calendar of Early Mavor's Court Rolls. Abstracts from these have been published for the period 1298-1307; ${ }^{166}$

- Other texts on London. As well as the above, there is a wealth of other texts on the City, including many chronicles. ${ }^{167}$

\section{(b) City of London - Cheating - Examples}

The City in early medieval times was highly regulated, with many 'mysteries' (trades) and guilds. They oversaw standards - together with the Mayor and Aldermen of the City who imposed fines and the pillory in the case of infractions. Particularly regulated was anything to do with food, drink and clothing. Further, the pillory was a very visible means of punishing petty frauds committed by bakers, brewers etc since the public could then identity them and, indeed, pelt them with insults and rotten food. ${ }^{168}$ All these infractions were later cited by Hawkins (in 1716-21) as examples of 'cheats' although that word did not come into usage until the $16^{\text {th }}$ century (being thieves' cant)(see 10(b)). Instead, in the times of the Plantagenets, the common words would have been 'deceites', 'malx faits' (evil deeds) and 'decepciones'. Thus the following may be noted:

- Assize of Bread. ${ }^{169}$ From early times, there were legal provisions designed to safeguard the weight and quality - of bread, it being a staple food. Prior to 1297, defaulting bakers were drawn though the streets on a hurdle. ${ }^{170}$ Indeed, this seems to have continued until, at least, 1437 (the hurdle being for the first offence and the pillory thereafter). ${ }^{171}$ Bread that was deficient was forfeited. ${ }^{172}$ Allegations against bakers were very common ${ }^{173}$ and ordinances of the City were often made regulating bakers; ${ }^{174}$

- Weights \& Measures. From Anglo-Saxon times there were detailed provisions on weights and measures, in order to prevent fraud and deception. ${ }^{175}$ In London, there was a great beam (also called the king's beam or tron) for weighing wool and other coarse goods. ${ }^{176}$ Also, a small beam for weighing silks and spices by the pound weight. ${ }^{177}$ These were to be used by the trades to weigh their goods (they were

\footnotetext{
${ }^{166}$ AH Thomas (ed), Calendar of the Early Mayor's Court Rolls preserved among the archives of the Corporation of the City of London at the Guildhall, AD 1298-1307 (Cambridge UP, 1924). See also RR Sharpe (ed), Calendar of Letters from the Mayor and Corporation of the City of London $c$ AD 1350-1370 enrolled and preserved among the archives of the Corporation at the Guildhall (London, 1885).

${ }^{167}$ McBain, n 143, pp 60-4. See also Chronicles of the Mayors and Sheriffs of London 1188-1274 (Trubner, 1863).

168 The thewe was also used in the case of women (it was a type of cucking stool). For the pillory and thewe, see McBain, n 39, pp 117-8.

${ }^{169}$ For texts, see Sweet \& Maxwell, A Legal Bibliography of the British Commonwealth of Nations (1955), vol 1, pp 383-4.

${ }^{170}$ Riley, n 162, p xli, 'on $30^{\text {th }}$ November 1297 'it was adjudged and ordered that the three beams, with their weights, newly ordained to weigh corn going to the mill, shall from henceforth be wholly abandoned; and that the hurdles on which bakers were drawn of late through the City, when convicted of selling false bread, that is, bread of insufficient weight, shall likewise be destroyed; the said bakers being from henceforth to have the punishment of the pillory.' See also Chronicles, n 167, p 43 (1258, bakers in tumbrel).

${ }^{171}$ Ibid, p xlii.

${ }^{172}$ Ibid, p 39, on 10 August, 1298, Juliana, the baker of Newington [Neytone] brought a cart laden with bread into the City (into West Chepe). Some of this was 'light' bread being 'wanting in weight, according to the assize of the halfpenny loaf, to the amount of 25 shillings' [in weight. The shilling of silver being three fifths of an ounce in weight, this deficiency was 15 ounces]. The defective bread was ordered to be given to the prisoners in Newgate. See also pp 71-2 (bread of Stratford seized as being deficient in weight). See also p 90. On 10 August 1311, an order was made for the arrest of a baker. It was asserted that his 'bread was putrid, and altogether rotten, and made of putrid wheat, so that persons by eating that bread would be poisoned and choked.' The sheriff was ordered to take the baker and bring him before the mayor and alderman, 'to receive judgment for the same.'

${ }^{173}$ Ibid, p 108 (charge of selling French bread of light weight), p 119 (light bread of deficient weight, punishment of the hurdle), p 121 (punishment for selling bread deficient in weight and of bad materials. 'bread of theirs made of false, putrid, and rotten materials; through which, persons who bought such bread were deceived, and might be killed.' Therefore, they were handed over for punishment by the pillory), p 122 (bread of deficient weight), p 498 (inserting iron into a loaf of bread to add to its weight).

174 eg. Ibid, p 180 (1331) 'Whereas the bakers of this city do withdraw themselves from the same, and hide in the mills and elsewhere in the foreign [ie. parts beyond the City and its liberties], to escape the punishment which they ought to have for their false loaves; and do put in their place their men and others who so make the loaves, false as to the weight and as to the dough thereof, the which things have not been permitted heretofore, - to the great damage and deceit of all the people.' See also The Assize of Bread and Ale (Assisa Panis et Cervisie)(temp incert, but probably Edward I (1272-1309), SR, n 109, vol 1, pp 199-200. Also, the Statute concerning Bakers (Statutum de Pistoribus)(1285?). Ibid, pp 202-4.

${ }^{175}$ See Sweet \& Maxwell, n 169 for texts. See also Chronicles, n 167, p 124 (1269, false weights, imprisonment in Tower of London). See also Assize of Weights and Measures (Assisa de Ponderibus et Menssuris)(1303?), SR, n 109, vol 1, pp 204-5.

${ }^{176}$ See McBain, n 52, p 23.

${ }^{177}$ See eg Riley, n 162, p 69 (In 1309, the small beam for weighing silk and spices, which belonged to the chamber of the City of London was let to Edmund le Lorimer [Edmund, the Lorimer] at a rent of $£ 10$ pa. 'And the aforesaid Edmund makes oath that he will give lawful weight to every one, and that he will faithfully do all other things which unto the said office pertain.'). See also, pp 72-4. The effect of the grant of the keepership of the small beam was that a person could then collect the fees for the weighing of goods and spices.
} 
usually charged a toll for this, called tronage). Those who sought to cheat by employing deceitful weights and measures were punished by the pillory. Thus, Riley cited examples of the pillory being used to punish those who sold coal and charcoal which was deficient in measure; ${ }^{178}$

- Weight of Vessels for Liquor ${ }^{179}$ These vessels - which were mainly made of wood - were regulated. ${ }^{180}$ Pewter vessels were also regulated ${ }^{181}$ as were vessels of gold and silver; ${ }^{182}$

- Taverns. Those who owned, or managed, taverns (taverners) were regulated ${ }^{183}$ as were the wines ${ }^{184}$ and ales they sold. Sellers of unsound wine were sometimes made to drink it as well as being pilloried. ${ }^{185}$ Hucksters of ale were also pilloried; ${ }^{186}$

- Fish. Dorsers - baskets in which fish were carried on packhorses (they were required to be of such a size as to hold one bushel of oats) - were regulated. Defective dorsers were destroyed and the fish forfeited. ${ }^{187}$ The pillory was imposed for selling putrid fish. ${ }^{188}$ Unlawful fish nets (kedels) were condemned to be burnt; ${ }^{189}$

- Meat. Punishment of the pillory was usual for the selling of putrid beef ${ }^{190}$ as well as for selling other putrid food. For example, carrion, ${ }^{191}$ putrid capons and pigeons. ${ }^{192}$ Hides could be forfeited for being badly tanned ${ }^{193}$ and shoes could be forfeited for being made of unlawful materials; ${ }^{194}$

- Hats. A huge range of clothing was regulated. Thus, hats were regulated and those of prohibited material were destroyed. For example, in 1311, after an examination of hats by certain scrutiniers, 40 grey and white hats and 15 black hats belonging to certain hatters 'of false workmanship, and a mixture of wool and flocks' were ordered to be burnt in the streets of Chepe. ${ }^{195}$ So too, false blankets, ${ }^{196}$ false gloves, ${ }^{197}$ false cushions and blankets, ${ }^{198}$ false caps etc $;{ }^{199}$

- $\underline{\text { Pots. }}$. These were also regulated. ${ }^{200}$ So too, dice and chequer boards. ${ }^{201}$

Thus, what, today, are treated as infractions of statutes relating to weights and measures and food were punished

\footnotetext{
${ }^{178}$ Ibid, p 446 (sacks of coal of short measure), p 673 (selling charcoal in sacks in deficient measure), p 669 (charcoal in deficient measure).

${ }^{179}$ See $\mathrm{n} 175$ for texts on the Assize of Ale.

${ }^{180}$ Ibid, p 78. On 21 December 1310, certain wood turners swore that 'in future they will not make any other measures than gallons, potells [measure of two quarts], and quarts; and that they will make no false measures....and that all such false measures...they will attach, and will cause the same to be brought to the Guildhall, before the Mayor, and present the same, on pain of heavy amercement, etc.' See also p 234 (enactmemt as to marking liquid measures made by the turners). Ibid, p 347 (false measures called chopyns ordered to be burnt).

${ }^{181}$ Ibid, p 259 (false saltsellers and potells of pewter forfeited).

${ }^{182}$ Ibid, p 337 (pillory for selling rings of latten for gold and silver), p 363 (pillory for selling circlets of inferior metal for silver), p 397 (imprisonment for silvering buttons and circlets of inferior metal), p 418 (substituting counters for gold).

183 eg. Riley, n 162, p 180 (1331, Ordinance against Bakers and Taverners).

${ }^{184}$ Ibid, p 213.At p 670 (proclamatiom against the adulteration and mixing of wines). At p 672 (adulterating wines). See also Chronicles, $\mathrm{n} 167$, p 75 (1264, regulation of measures of wine).

${ }^{185}$ Ibid, p 318 (seller of unsound wine punished by being made to drink it), p 408 (unsound wines condemned).

${ }^{186}$ Ibid, p 390.

${ }^{187}$ Ibid, pp 116-7 (1315, dorsers for fish, of unlawful measure, ordered to be burnt in Chepe).

${ }^{188}$ Ibid, p 464 (putrid conger eel), p 471 (importing putrid fish, importer respited for being king's servant), p 516 (inquisition as to putrid fish being brought into the City), p 367 (thewe for selling putrid soles).

${ }^{189}$ Ibid, pp 171, 214, 483, 486 (unlawful nets called 'burrokes').

${ }^{190}$ Ibid, p 132 (selling putrid beef, pillory), p 138 (putrid meat), p 139 (false charge of intending to sell putrid meat, pillory).

${ }^{191}$ Ibid, pp 240, 270.

192 Ibid, p 266. See also p 328. At p 448 (putrid pidgeons).

193 eg. Riley, n 162, p 135. At p 420 (hides forfeited for being badly tanned).

${ }^{194}$ Ibid, p 136.

${ }^{195}$ Ibid, pp 90-1.

${ }^{196}$ Ibid, p 212 ('ten false blankets that have been vamped in foreign parts with the hair of oxen and cows.' Ordered to be burnt).

${ }^{197}$ Ibid, p 249 (false gloves, braels and pouches burnt in Chepe).

${ }^{198}$ Ibid, p 260.

${ }^{199}$ Ibid, p 529 (false caps ordered to be burnt in Chepe).

${ }^{200}$ Ibid, p 118 (complaint of potters as to frauds committed in their trade. Pots sold as being of brass were of defective metal 'to the deception of all those who buy such pots: for the moment that they are put upon the fire, and become exposed to great heat, they come to nothing, and melt. By which roguery and falsehood the people are deceived, and the trade aforesaid is badly put in slander.').

${ }^{201}$ Ibid, p 395 (cheating with false tables and dice), p 457 (false dice), p 455 (chequer board).
} 
by virtue of the common law. And what, today, would be described as selling by way of mis-description or fraudulent mis-representation were categorised under a generic concept of 'deceites' (frauds). They are all examples of swindling. It is important to note that these deceits were different from cheating the public revenue for the following reasons:

- They derived from the law of common nuisance. Thus, the punishment was the pillory or thewe. In contrast, cheating the public revenue was a misprision and it derived from the law on contempt of the sovereign. Thus, the punishment was fine (sometimes imprisonment), loss of lands and, sometimes, loss of office;

- Cheats against the public were judged by the Mayor and Alderman of the City of London. In contrast, cheating the public revenue was judged by the Exchequer courts or the King's Bench;

- Cheats against the public were committed by commission but not by omission. Contrariwise, cheating the public revenue was a misprision and could be committed by omission.

In conclusion, in the City of London, from medieval times, persons were punished by the pillory for a whole range of deceits (cheats) which had the effect of swindling the general public. These deceits were different from cheating the public revenue.

\section{False Tokens - 1541}

For a long time the offence of cheating (ie defrauding persons in certain contexts) comprised only a common law offence. However, in 1541, statute entered the field with an 'Act concerning Counterfeit Letters or Privy Tokens $^{202}$ to receive Money or Goods in other Men's Names' (spelling modernised). ${ }^{203}$ The purpose of the Act was recited in its Preamble:

For as much as many light and evil-disposed persons, not minding to get their living by truth according to the laws of this realm, but compassing and devising daily how they may unlawfully obtain and get into their hands and possession goods, chattels, and jewels of other persons, for the maintenance of their unthrifty living, and also knowing that if they came to any of the same goods, chattels, and jewels by stealth, that then they, being thereof lawfully convicted according to the laws of this realm shall die, therefore, have now of late falsely and deceitfully contrived, devised, and imagined privy tokens and counterfeit letters in other men's names, unto divers persons their special friends and acquaintances, for the obtaining of money, goods, chattels, and jewels of the same persons, their friends and acquaintances, by colour whereof the said light and evil disposed persons have deceitfully and unlawfully obtained and gotten great substance of money, goods, chattels, and jewels into their hands and possession, contrary to right and conscience:

For the reformation whereof it is enacted...that if any person or persons... falsely and deceitfully obtain or get into his or their hands or possession, any money, goods, chattels, jewels, or other things of any other person or persons, by colour or means of any such false token, or counterfeit letter made in any other man's name, [then, punishment of pillory or other corporal punishment except death].(spelling modernised).

This legislation of 1541 was one of the first to directly deal with a crime relating to deception and it initiated the process of the law punishing the acquiring of money and property by false pretences ${ }^{204}$ - one latter extended by an Act of 1757 (obtaining money by false pretences) ${ }^{205}$ and an Act of 1812 (obtaining bonds etc under false pretences). ${ }^{206}$ Hawkins noted:

\footnotetext{
${ }^{202}$ The word 'token' was replaced in later legislation with the word 'pretence'. OED (token), n 128, 'A stamped piece of metal, often having the general appearance of a coin, issued as a medium of exchange by a private person or company, who engage to take it back at its nominal value, giving goods or legal currency for it.' Note. From the reign of Queen Elizabeth to 1813, issued by tradesmen, large employers of labour etc. to remedy the scarcity of small coin, and sometimes in connection with the tick-shop system.'

${ }^{203} 33$ Hen VIII c 1 (rep 1827). See also 6 Hen 4 (1404) c 3 (commissioners to enquire of the accounts of sheriffs and customers and other king's officers and in the country and passed in the Exchequer, and if they are detected in any fraud, to incur triple damages). See also Thomas, n 52, p 5 .

${ }^{204}$ See the analysis of Hawkins (1824 ed), n 10, vol 1, pp 319-22.

${ }^{205} \mathrm{Ibid}, \mathrm{p} 321$ 'the stat 30 Geo 2 c 24 was enacted, by which it was made penal to obtain money, goods, wares, or merchandizes by 'false pretences'.

${ }^{206} 52$ Geo 3 c 64 s 1 which enacted that 'all persons who knowingly and designedly, by false pretence or pretences, shall obtain from any person or persons, or from any body politic or corporate, any money, goods, wares, or merchandizes, or any bond, bill of exchange, bank note, promissory note, or other security for the payment of money, or any warrant or order for the payment of money, or delivery or transfer of goods or other valuable thing, with intent to cheat or defraud any person, etc shall be deemed offenders against law and public peace, and shall be
} 
The common law punishing only those cheats which were effected by means of false public tokens, or by conspiracy or by forgery, or which effected the public interest, the statute of Henry the $8^{\text {th }}$ (ie. the Act of 1541) went further, and punished those cheats which were effected by means of ' $a$ false privy token or counterfeit letter made in another man's name to a special friend or acquaintance' but this extension of the law being found inadequate to repress the practice of the fraudulent, the stat [ute of 1757] was enacted...But this latter statute did not include choses in action and therefor [the Act of 1812 was enacted]. ${ }^{207}$

In conclusion, the common law on deceit (cheat) was supplemented by legislation, which legislation was not repealed until 1827. This legislation punished acquiring by false pretences. It did not relate to defrauding the revenue as such.

\section{Staunford (1557), Pulton (1609) \& Coke (1641)}

Staunford - who wrote the first treatise on criminal law in $1557^{208}$ - did not deal with cheating the revenue. Nor did Pulton in his De Pace Regis et Regni (1609). ${ }^{209}$ Nor did Coke in the third part of his Institutes of the Laws of England (published in 1641). However, Coke did refer to the Act of 1541 (see 9). ${ }^{210}$ Two other matters may be referred to with regard to this period:

\section{(a) Cheating the Revenue - Misprision}

It is asserted this offence was (and is) a misprision. Coke said of misprision:

Misprision is twofold: one is crimen omissionis, of omission, as in concealment, or not discovery of treason or felony; another is crimen commissionis, of commission, as in committing some heinous offence under the degree of felony. Or [of] misprision is of two sorts, viz passive and active: passive is of the nature of the concealment, whereof some be by the common law, and some by statute. ${ }^{211}$ (spelling modernised)

Similarly, Blackstone said as to misprision:

Misprisions (a termed derived from the old French, mespris, a neglect or contempt) are, in the acceptation of our law, generally understood to be all such high offences as are under the degree of capital, but nearly bordering thereon: ...Misprisions are generally divided into two sorts; negative, which consist in the concealment of something which ought to be revealed; and positive, which consist in the commission of something which ought not to be done. ${ }^{212}$

An offence allied to cheating the public revenue which was also a misprision was misconduct in a public or judicial office. ${ }^{213}$

\section{(b) Meaning - Cheat}

In early times, the word commonly used to describe cheating the revenue was 'deceite'.

\footnotetext{
liable to be prosecuted and punished in a like manner as if they had knowingly and designedly, by false pretence or pretences, obtained any goods, wares, or merchandizes, from any person or persons, with intent to cheat or defraud any person or persons of the same.' The punishment was the pillory. See Hawkins (1824 ed), n 10, vol 1, p 321 who referred to $R v$ Young [see n 251] where Buller J 'says that the offence within the statute is 'the obtaining by false pretences with intention to defraud', that if the intent were made out, and the false pretence used to effect it, the case was brought within the statute.'

${ }^{207}$ Hawkins (1824 ed), n 10, vol 1, pp 320-1.

${ }^{208}$ W Staunford, Les Plees del Coron (Richard Tottell, $1^{\text {st }}$ ed, 1557, $2^{\text {nd }}$ ed, 1607) reprinted by the Law Book Exchange.

${ }^{209}$ F Pulton, De Pace Regis et Regni (London, Company of Stationers, 1609) reprinted by the Law Book Exchange. Pulton did, however, look at cheating in respect of weights and measures and victuals etc, updating the medieval position (see 8), much of which had become, by 1609 (when he wrote), statutory. Ibid, pp 80-2. He called these forms of cheat, 'deceits'.

${ }^{210}$ Coke, n 9, vol 3, p 133.

${ }^{211}$ Ibid, $\mathrm{p} 139$. He continued 'By the common law, as passive misprision, that is concealment of high treason whereof we have spoken; and passive misprision, that is concealment of felony, whereof we are now in this chapter to speak. Some by statute: as if any be moved to make commotion or unlawful assembly, and do not within twenty four hours declare the same to a justice of peace, sheriff, mayor, or bailiff etc.concealment by juries...' (spelling modernized). See also n 127, making a false return was a misprision.

${ }^{212}$ Blackstone, n 12, vol 4, p 119

${ }^{213}$ Ibid, ch 9. It may be noted that, in former times, neglect of duty, bribery and extortion, were offences committed by an officer only, eg. M Hale, Pleas of the Crown (1685), p 134 'Offences of an inferior nature: they are either such as are committed by an officer, neglect of duty, bribery, extortion. Or such as refer to a common person, without relation to office etc.'
} 
- This is unsurprising since the Oxford English Dictionary indicates that the word 'cheat' only came into use post 1530 and that it (probably) derives from thieves' cant (speech), referring to a stolen article; ${ }^{214}$

- However, the word 'cheat', as a verb, was - when in general usage - employed as a synonym for 'to defraud $^{215}$ and one would suggest that - today - this would be a more intelligible word to use.

As to the word 'cheat', one assumes that - from thieves' cant - it percolated into more general use and, then, was used in court and by legal writers in due course. In the case of the former, in Orbell (1703) the word 'cheat' is used. ${ }^{216}$ In the case of the latter, Hale CJ - in The History of the Pleas of the Crown ${ }^{217}$ written c 1640's - in a chapter entitled 'Of Larceny, and its kinds', referring to the Act of 1541(see 9), stated:

If A comes to B and by a false message or token receives money of him, and carries it away, it is no felony, but a cheat punishable by indictment at common law, or upon the statute of $33 \mathrm{H} 8$ cap 1 [ie. the Act of 1541, see 9] by setting in the pillory. ${ }^{218}$ (italics supplied)

This appears to be an early use of the word 'cheat' in the legal textbooks.

In conclusion, the word 'cheat' came in to legal use to cover what the Anglo-Norman word 'deceite' embraced in medieval times.

\section{Hawkins - Pleas of the Crown: 1716-21 \& 1824}

The first systematic analysis of the concept of 'cheating' appears to have been Hawkins who - in the first edition of his Treatise of the Pleas of the Crown (1716-21) - considered the offence 'Of Cheats'. He observed:

Of cheats punishable by public prosecution, there are two kinds, 1. By the common law. 2. By the statute. ${ }^{219}$

Hawkins 'packaged' together a number of disparate examples of cheat, culled from the law reports. Thus, he stated:

And first it seemeth, that those which are punishable at common law, may in general be described to be deceitful practices in defrauding or endeavouring to defraud another of his known right by means of some artful device contrary to the plain rules of common honesty.

Hawkins then cited various examples by reference to the caselaw: ${ }^{220}$

- Playing with false dice;

- Causing an illiterate person to execute a deed to his prejudice, by reading it over to him in words different from those in which it was written;

- Persuading a woman to execute writings to another (as her trustee upon an intended marriage), which in truth contains no such thing, but only a warrant of attorney to confess a judgment etc;

- Suppressing a will;

\footnotetext{
${ }^{214}$ OED (cheat), n 128, '3. Thieves' Cant [ie speech]. According to Randall Holme, orig. A stolen thing - but as early as Harman's date (1567) used in general sense 'thing' 'article'; usually preceded by some descriptive word.' Theives cant (also called Pedlers' French) may have derived from romany gypsies (Egyptians) and it started to be used in England c. 1530's onwards. See generally, T Harman, A Caveat or Warening for Common Cursetors vulgarely called Vagabones (ed. E Viles \& FJ Furnivall, London. Published for the Early English Text Society, 1869). 'Cheatours' (or 'Fingerers') was a reference, in particular, to card sharpers which is why cases discussed by legal writers often included references to false dice and other gaming tricks, by which the general public were fleeced. See also the Early English Text referred to previously, 7 (description of a cheatour or fingerer in J Awdeley (printer), The Fraternitye of Vacabondes (1575)).

${ }^{215}$ OED (to cheat), $\mathrm{n} 128$, '2. To defraud, to deprive of by deceit. 3a To deceive, impose upon, trick. B.To lead into (action) by deception. 4 . To deal fraudulently, practice deceit.' See also J Cowell, A Law Dictionary or the Interpreter (London, 1708) 'Deceptio, fraus, dolus, is a subtle, wily shift or device, having no other name. Hereto may be drawn all manner of craft, subtilty, guile, fraud, wileness, slight, cunning, covin, collusion, practice and offence us'd to deceive another man by any means, with hath none other proper or particular name, but offence.' Cowell cited W West, Symboleography (London, 1641), pt 2, section 68 'Enough of named offences, it remains that we view those which be unnamed...Deceit is a subtle wily shift or device having none other name. Hereunto may be drawn all manner of craft, subilty, guile, fraud, wileliness, sleightness, cunning, covin, collusion, deceit, device, practice, and offence used to deceive another man by any means, which has none other proper or particular name but offence.' (wording modernized). Cowell's definition was repeated in T Blount, A Law Dictionary and Glossary (3 $\left.3^{\text {rd }} \mathrm{ed}, 1717\right)$.

${ }^{216} R v$ Orbell (1703) 6 Mod 42 (87 ER 804). In an indictment for cheating in a footrace 'The court would not grant it [the indictment] upon motion, for they said, that being a cheat, though it was private, in the particular, yet it was publick in its consequences.' (italics supplied)

217 See $n 11$.

${ }^{218}$ Ibid, vol 2, p 506.

${ }^{219}$ In the case of statute, Hawkins cited the Act of 1541 (see 9).

${ }^{220}$ I do not cite the cases since they are all now obsolete.
} 
- Levying a fine in another person's name;

- Suing out an execution on a judgment for a person;

- Acknowledging an action in a person's name without his privity, and against his will.

It may be noted there was no reference to 'Cheating the Public Revenue' in this, the first edition of Hawkins, nor in the examples referred to. ${ }^{221}$ Nor was there mention in the 6 th edition of his work, in 1788. For the final edition of Hawkins (in 1824) where reference was made to cheating the public revenue, see 15(b).

In conclusion, Hawkins dealt with cheating both at common law and pursuant to legislation. However, he did not discuss cheating - in the context of cheating the public revenue - until after East had considered this in 1803 (see 14).

\section{Blackstone (1769)}

Blackstone, in the fourth volume of his Commentaries on the Laws of England (in 1769), in a chapter on 'public wrongs', stated:

Cheating is another offence, more immediately against public trade; as that cannot be carried on without a punctilious regard to common honesty, and faith between man and man. Hither therefore may be referred that prodigious multitude of statutes, which are made to prevent deceits in particular trades, and which are chiefly of use among the traders themselves. For so cautious has the legislature been, and so thoroughly abhors all indirect practices, that there is hardly a considerable fraud incident to any branch of trade, but what is restrained and punished by some particular statute. ${ }^{22}$

Blackstone then went on to mention breaking the assize of bread, ${ }^{223}$ as well as false weights and measures ${ }^{224}$ and he noted the punishment. ${ }^{225}$ Blackstone continued:

Lastly, any deceitful practice, in cozening ${ }^{226}$ another by artful means, whether in matters of trade or otherwise, as by playing with false dice, or the like, is punishable with fine, imprisonment, and pillory.

And by the statutes 33 Hen VIII c 1 and 30 Geo II c 24 [see 9] if any man defrauds another of any valuable chattels by colour of any false token, counterfeit letter, or false pretence, or pawns or disposes of another's goods without the consent of the owner, he shall suffer such punishment by imprisonment, fine, pillory, transportation, whipping, or other corporal pain, as the court shall direct. ${ }^{227}$

In conclusion, Blackstone did not deal with cheats affecting the public revenue but only with cheating individuals and the general public.

\section{Bembridge (1783)}

\section{(a) Locus Classicus}

This case ${ }^{228}$ is an important one in that it has been cited as the locus classicus in the context of:

(i) misconduct in a public office;

\footnotetext{
${ }^{221}$ These are all examples of what Roman law would regard as swindling (ie. stellionatus, as opposed to embezzling public money under the Lex Julia). See n 133.

222 Blackstone, n 12, vol 4, p 157.

${ }^{223}$ Ibid. 'The offence also of breaking the assize of bread, or the rules laid down by law, and particularly by statute 31 Geo II c 29 [1757, rep] and 3 Geo III c 11 [1762, rep] for ascertaining its price in every given quantity, is reducible to this head of cheating..' Also, 'The punishment of bakers breaking the assize, was anciently to stand in the pillory, by statute 51 Hen III st 6 [1266, rep] and for brewers (by the same Act) to stand in the tumbrel or dungcart: which, as we learn from Domesday book, was the punishment for knavish brewers in the city of Chester so early as the reign of Edward the Confessor [1042-66]. 'Malam cervisiam faciens, in cathedra ponebatur stercoris." (those making bad beer used to be put in the dungcart).

${ }^{224}$ Ibid, p 157.

${ }^{225}$ Ibid. 'But now the general punishment for all frauds of this kind, if indicted (as they may be) at common law, is by fine and imprisonment: though the easier and more usual way is by levying a summary conviction, by distress and sale, the forfeitures imposed by the several acts of parliament.'

226 'Cozen' meant the same as cheat. OED (cozen), n 128, '1. To cheat, defraud by deceit. 2. To cheat (out) of. The OED also notes 'The earliest trace of the word appears to be in the derivative cousoner in Awdelay's Fraternitie of Vacabondes, 1561 (see cozener); it is not improbable that it arose among the vagabonnd class.' See also $\mathrm{n} 214$.

${ }^{227}$ Ibid, pp 157-8.

${ }^{228} 3$ Burr 1317 (97 ER 851). See also (1783) 22 ST 1 (where the facts are more fully reported). For a useful $18^{\text {th }}$ century text indicating the statutes relating to the liability of sheriffs, and others, to account at this time - as well as customs, debts to the king, estreat, exchequer etc see $\mathrm{G}$ Jacob, The Statute Law Commonplaced (printed E \& R Nutt, $3^{\text {rd }}$ ed, 1731).
} 
(ii) false accounting;

(iii) cheating the public revenue.

The case is a good example of all three and it indicates that - in 1783 - these common law offences had not become independent offences as they are today. Further, (ii) is covered, today, by the Theft Act 1968, s 17 (false accounting).

\section{(b) The Case - Historical Background}

In this case, the defendant - an accountant in the office of the Receiver and Paymaster General of the Forces deceitfully (ie. corruptly) ${ }^{229}$ concealed from his superior his knowledge that certain sums which should have been inserted into a final account were omitted (the sum was a debt of $£ 48,000$ owed by Holland to the public, that is, the Exchequer). ${ }^{230}$ The case appears opaque unless some historical background is understood.

- Henry Fox, 1st Baron Holland (1705-74), the father of Charles James Fox the politician, was appointed Paymaster General of the Forces in the period 1757-65 when he was forced to resign. He was said to have amassed some $£ 50,000$ a year from the office in his eight years there. ${ }^{231}$ Proceedings against Fox were brought in the Court of Exchequer. However, they were delayed by a Royal warrant. Further, Fox proved that - in the delay in making up the accounts in his office - he had not broken the law. However, from the interest on the outstanding balances, he made a fortune; ${ }^{232}$

- Fox died in 1774. His acting executor was John Powell was also the accountant general in the Office of the Receiver and Paymaster General of the Forces and - as such - responsible for the closing of Holland's account. In 1776, Bembridge succeeded Powell (who nominated him) ${ }^{233}$ as accountant general in the office of the Receiver and Paymaster General of the Forces. ${ }^{234}$

- In 1783, an information was brought against Bembridge and Powell by the Attorney-General for a misdemeanour. Powell committed suicide in 1783 (doubtless, because of the scandal) and, therefore, was never brought to trial; ${ }^{235}$

- The gist of the case was that Powell and Bembridge failed to close Holland's account for many years (ie. 1774-83), the effect of which would have been to show that a large sum was owing to the Exchequer (ie. the balance on the account was $£ 48,000$ less than it actually was). ${ }^{236}$ Further, that Bembridge knowingly and fraudulently failed to disclose the omission in the supposed 'final' account;

\footnotetext{
229 Ibid. It was said, p 1328, that Bembridge 'well knew' several sums had not been included in the final account.

${ }^{230}$ The information against Bembridge was that he 'wrongfully, unjustly, and fraudulently' contrived and intended to conceal the sum 'to cheat and defraud our...sovereign lord the king'. 22 ST p 21 and that he 'wickedly, wilfully, fraudulently, knowingly and corruptly did neglect and refuse' to discover or make known the absence of a missing sum. Ibid, p 22. See also $\mathrm{p} 28$.

${ }^{231}$ In 1769, a petition of the livery of the City of London delivered by the Lord Mayor (William Beckford) against the Ministers of the Government, described Fox as 'public defaulter of unaccounted millions.' See also GO Trevelyan, The Early History of Charles James Fox (Longmans, 1899), pp 24-6.

${ }^{232}$ See ODNB, n 139 'From the late 1730s he had a healthy income from political office, but this was dwarfed by the profits which he derived from the paymastership during and after the Seven Years' War. These came largely from speculating (quite legally) with the vast balances of public money that passed through his hands, an opportunity which did not end in 1763 thanks to the very lengthy delays involved in auditing his accounts. As late as 1773 his indebtedness to the public was more than $£ 500,000$ and his unofficial profits as paymaster probably amounted to $£ 400,000$. Wealth on this scale was matched only by the opprobrium that followed in its train.' See also F Anderson, Crucible of War (Vintage Books, 2001) and LS Sutherland \& J Binney, Henry Fox as Paymaster General of the Forces. English Historical Review (1955) vol 70, pp 229-57.

${ }^{233} 22$ ST p 97. Did Bembridge financially benefit from the concealment? His counsel suggested not, p 57. Cf Willes J, p 159 'You were privy to this cheat, and were at least a principal in the second degree: what share you had in the plunder is best known to yourself; but that the court cannot suppose you were weak enough to be concerned in so gross a fraud without receiving some private advantage from it.'

${ }^{234} \mathrm{He}$ was appointed accountant in succession to Powell when the later took on the more senior role of Cashier. See 22 ST p 29.

${ }^{235}$ It seems that Powell obtained financial advantage from failing to disclose. 22 ST p 159 per Willes J 'Mr Powell availed himself of the interest and profits of 116,000 pounds, of which the public was defrauded.'

${ }^{236}$ When Bembridge became accountant general in 1776 it became his duty to close Holland's account. It seems likely that he became aware (if not before) of the large sum owing by Holland (of $£ 48,000$ ) which Powell had failed to disclose. Bembridge then failed to do the same, declaring that his account contained all the sums owing. $22 \mathrm{ST}$ at $\mathrm{p}$ 32. It seems that Bembridge may have done so since Powell was a friend, associate and benefactor. $22 \mathrm{ST}$ at $\mathrm{p} 68$. The net effect of all this was that the balance of Holland's account was ' $£ 48,000$ less than it really was'. Ibid, at p 71. Further, Bembridge had concealed this from 1776 (when he was accountant) until 1782 (6 years). Ibid, per Mansfield CJ at $\mathrm{p} 74$.
} 
- The fact that no loss was actually incurred (or could be incurred) was strongly asserted by counsel for Bembridge. ${ }^{237}$ Although this was not specifically discussed by Mansfield CJ in his judgment, this was irrelevant since the offence was (and is) a misprision (see 10(a)). Thus - as well as being able to occur by omission as commission - the conduct is the thing that is punished (being a contempt of the sovereign), not the consequence of the conduct. ${ }^{238}$

\section{(d) The Case - Judgment}

\section{Giving judgment in the case, Mansfield CJ stated: ${ }^{239}$}

The duty of the defendant is obvious; he was a trustee for the public and the paymaster, for making every charge and every allowance he knew of...If the defendant knew of the omission...if he concealed it, his motive must have been corrupt. That he did know was fully proved, and he was guilty therefore, not of an omission or neglect, but of a gross deceit. [fraud] The object could only have been to defraud the public of the whole, or part of the interest.$^{240}$

Here there are two principles applicable: first, that a man accepting an office of trust concerning the public, especially if attended with profit; is answerable criminally to the king for misbehaviour in his office; this is true, by whomever and whatever way the officer is appointed...

Secondly, where there is a breach of trust, fraud, or imposition, in a matter concerning the public, though as between individuals it would only be actionable, yet as between the king and the subject it is indictable. That such should be the rule is essential to the existence of the country.

An indictment has been sustained for concealing public money, 27 Ass pl 17, ${ }^{241}$ though this, as against a private person, would only have been actionable. ${ }^{242}$ The rule is well laid down by Mr Serj. Hawkins ${ }^{243}$ that all kinds of crimes of a public nature, all misdemeanours whatsoever of a public evil example against the common law may be indicted; but no injuries of a private nature, unless they some way concern the king. So it is laid down in an Anonymous case, ${ }^{244}$ that any public officer is indictable for misbehaviour in his office. No doubt the offices concerning the revenue are of great importance to the public ${ }^{245}$ (italics supplied)

In conclusion, Bembridge is principally a decision on false accounting. However, since it concerned a public officer, it is also an offence relating to misconduct by a public officer. Finally, since it related to the public

\footnotetext{
${ }^{237} 22$ ST 150 'the public will never suffer either by the default of Mr Bembridge or Mr Powell, for there are standing securities for the balance of all lord Holland's accounts, amounting to upwards of 100,000 pounds, upon landed security, the same securities that they stood upon at the time of lord Holland's death; it is perfectly clear, therefore, that the public cannot lose by this.'

${ }^{238}$ See n 212 (mespris, contempt).

239 J Oldham, The Mansfield Manuscripts (Univ of North Carolina Press), p 936 indicated that Mansfield's trial notes add nothing to the case.

${ }^{240}$ This wording is important since Mansfield CJ clearly adverted to the need for a dishonest intention (ie. knowing and dishonest, dolus malus) and that this dishonest intention was to 'defraud the public.' This is the heart of this common law offence - an intent to defraud.

${ }^{241} 27 \mathrm{Ass}$ pl 17. This is a reference to $27 \mathrm{Edw}$ (1353) Liber Assisarum (Book of Assizes), pl 17 fo 135a, Seipp no 1353.142ass (presentment for withholding money levied for the array of archers). Seipp translates the Anglo-Norman as: 'It was presented that G of L and another had levied 100 marks from the county for the array of certain archers, which money (den's) never came to the profit of the king.' See also Brooke, $\mathrm{n} 20$, Fees del Court, 11. Translations of many of the 22,000 cases in the Yearbooks have been published online by professor David Seipp in the form of an Index, www.bu.edu/law/faculty/scholarship/yearbooks)._The Book of Assizes (Liber Assissarum)(Criminal cases in time of Edward III, 1327-77) has been reprinted by the Law Book Exchange, see www.lawbookexchange.com/. The Liber was first published in 1516 (J Rastell). This case was cited by Coke CJ in $R v$ Haukes (1615) 1 RR (81 ER 283) where he stated that a person who collected murage (ie. a toll for repairing city walls) but who did not account for it properly could be indicted the same as the collectors in 27 Ass pl 17 were indicted for a conversion of the money collected to supply archers ('si il ne ceo imploie accordantment il poet ester indicte, come est en 27 Ass car la fuit deniers collectes a furnish archers collector indicte por conversion de eo al son use demesne.').

${ }^{242}$ The distinction was almost the same under Roman law. Swindling was not a public (or, indeed, a private) process. However, embezzlement under the Lex Julia was a crime of a public nature and prosecuted as such by the public authorities. See also $n 133$.

${ }^{243}$ Mansfield CJ cited Hawkins,n 10, book 2, c 25, s 4 (see e.g. $3^{\text {rd }}$ ed, 1739 'What matters are indictable: There can be no doubt, but that all capital crimes whatsoever, and also all kinds of inferior crimes of a public nature, as misprisions, and all other contempts, all disturbances of the peace, all oppressions, and all other misdemeanours whatsoever of a publicly evil example against the common law, may be indicted; but no injuries of a private nature, unless they some way concern the king.).'

${ }^{244}$ Anon (1704). 6 Mod 96, case 136 (87 ER 853). It was stated per curiam 'If a man be made an officer by Act of Parliament, and misbehave himself in his office, he is indictable for it at common law, and any publick officer is indictable for misdemeanor in his office.'

${ }^{245}$ At pp 331-2.Willes and Buller JJ concurred. In his comments Mansfield CJ cited A Vidian, The Exact Pleader (printed by W Rawlins et al, 1684), p 213 (an information in 1653 against the custos brevium of the King's Bench for neglect of his duty, being the losing of a record). The custos brevium was the senior clerk of the King's Bench. See also 22 ST p 156.
} 
revenue, it is also a case of cheating the public revenue. ${ }^{246}$

\section{East (1803)}

East - in the only edition of his Treatise of the Pleas of the Crown (1803), ${ }^{247}$ - drew a distinction between larceny and cheats. In the latter case, the owner intended to dispose of the absolute property in the goods in question. $^{248}$ However, East also noted that:

the intent in both instances being dishonestly to acquire and convert to his own use the property of another without any or an adequate consideration. ${ }^{249}$ (italics supplied)

East then went on to consider various forms of cheat. He analysed 'false tokens' ${ }^{250}$ (the law on this is no longer relevant $)^{251}$ and then doubted whether Hawkins' definition of the offence of cheating ${ }^{252}$ was sufficient, or distinct, to be taken as a definition of the offence at common law. He stated:

I should rather say that it consists in the fraudulent obtaining the property of another by any deceitful or illegal practice or token (short of felony) which affects or may affect the public. ${ }^{253}$

\section{(b) Public Cheats}

In respect of this, East discussed false weights and measures ${ }^{254}$ and then cheats against public justice, stating:

There is also another head of public cheats, indictable at common law, which are levelled against the public justice of the kingdom. Such as the doing judicial acts without authority in the name of another. But most of these are now made felony by the statutes 21 Jac 1 c 26 and $4 \mathrm{~W} \mathrm{\&} \mathrm{M} \mathrm{c} 4 .^{255}$ There is precedent of an indictment against a married woman for pretending to be a widow, and as such executing a bail-bond to the sheriff for one arrested on a bailable writ. This perhaps was considered as a fraud upon a public officer in the course of justice. ${ }^{256}$

East continued:

So all frauds affecting the crown and the public at large are indictable, though arising out of a particular transaction or contract with the party. This is admitted by the very terms of the objection in the

\footnotetext{
${ }^{246}$ Mansfield CJ's analysis (one would assert) was wholly in accordance with early English law. Cheating the revenue was a contempt against the sovereign (against his Exchequer). It was a misprision which could be committed by way of omission or commission. Further, it required neither deception or a loss to be proved. See, for example, the cases cited in 7.

${ }^{247}$ EH East, $A$ Treatise of the Pleas of the Crown (1803) reprinted by the Lawbook Exchange Ltd.

${ }^{248} \mathrm{Ibid}, \mathrm{vol} 2, \mathrm{p} 816$ 'Upon reviewing the authorities there collected it will appear that the distinction so far as regards the subject of the present inquiry turns mainly upon the consideration whether or not the owner deceived by appearances intended to part with the absolute property, and not barely with the possession or temporary use of the thing at the time of the delivery, rather than upon any actual difference in the degree of fraud meditated by the taker...'

249 Ibid.

${ }^{250}$ See, in particular, the Act of 1541 (see 9).

${ }^{251} \mathrm{He}$ stated 'It is not however every species of fraud or dishonesty in transactions between individuals which is the subject matter of a criminal charge at common law; but in order to constitute it such, according to the doctrine in Wheatly's Case, Young's case, and other authorities, it must be such as affects the public; such as is public in its nature, calculated to defraud numbers, to deceive the people in general. And this is instanced not only by precedents of cheats effected by conspiracy, to which may be added forgery, which are in themselves substantive offences, though the cheats thereby intended be not fully carried into effect; but also, as is stated generally, by such as effected by means of false tokens. Yet these latter being also, put by way of example, must still, as it seems, be understood of such false tokens as affect the public at large, such as are calculated to defraud numbers, to deceive the people in general; of which the common instance referred to is the cheating by means of false weights and measures, against which it is said that ordinary care or prudence is not sufficient to guard. It does not distinctly appear that the instances so put in argument, of cheats effected by means of false tokens generally, were intended to be applied indiscriminately to offences at common law as well as by statute; but such expressions seem rather to have been used concerning cheats in general which were the subject matter of an indictment, which would of course comprehend those included in the stat. 33 H 8 [ie. Act of 1541, see 9].' For Wheatly's case see 2 Burr 1125 (97 ER 746) (1761) and, for Young's case, see 3 TR 104 (100 ER 475)(1789).

${ }^{252}$ Hawkins had stated: 'That it consists in 'deceitful practices in defrauding or endeavouring to defraud another of his known right by means of some artful device contrary to the plain rules of common honesty'. See 11.

${ }^{253}$ East, $\mathrm{n} 247, \mathrm{p} 818$.

${ }^{254}$ Ibid, $\mathrm{p}$ 820. 'But if in any of these cases the cheat be effected by means of false weights or measures, (which are known public tokens) it is then clearly indictable; for these betoken a general design to defraud; they are instruments or tokens purposely calculated for deceit, and by which the public in general may be imposed upon without any imputation of folly or negligence...To [this] principle may also be referred the instances of cheats by means of playing with false dice etc...'

${ }^{255} 21 \mathrm{Jac} 1$ c 26 (1623, rep) and 4 W \& M c 4 (1692, rep).

${ }^{256}$ East, n 247, p 821.
} 
following case. ${ }^{257}$

East then went on to cite the following case:

Treeve (1796). ${ }^{258}$ The indictment charged that Treeve (a common brewer and a Government contractor) knowingly, wilfully, deceitfully and maliciously did provide, furnish and deliver to and for 800 French prisoners of war in a prison near Plymouth, 500 pounds of bread, for food. And that the bread was unfit for consumption, making the prisoners ill to the great discredit of the lord the king, to the evil example etc and against the peace etc. After conviction it was objected - in arrest of judgment - that the offence as laid was not indictable since it did not appear that it was done in breach of contract with the public or of any moral or civil duty. The judges upheld the conviction. ${ }^{259}$ It is clear that East was not citing this case as one of cheating the public revenue but, rather, as one of the cheating the general public. ${ }^{260}$

East went on to mention the following case which is a good example of cheating the public revenue:

Jones (1777). ${ }^{261}$ The indictment charged that Jones (an apprentice) was bound by indenture to serve one Lucas (a jobbing smith) for the remainder of a term of 7 years and that - intending fraudulently and unjustly to obtain money from the paymaster of HM's $7^{\text {th }}$ regiment of foot to defraud the king of divers sums of money - Jones, unlawfully, fraudulently and deceitfully caused and procured himself without the consent of Lucas to be enlisted by means of which he unlawfully, fraudulently and deceitfully obtained payment, knowing himself to be disqualified from serving without his master's consent, to the great deceit, fraud and damage to the king, and against the peace etc. The indenture was produced but not the subscribing witnesses 'which upon reference to the judges after conviction was holden to be necessary in order to warrant the conviction. ${ }^{262}$

East then went on to discuss private cheats. Finally, East considered the Act of 1541 (see 9) and subsequent legislation relating to it. $^{263}$

In conclusion, East was the first legal writer to discuss cheats affecting the Crown as such - as opposed to the general public. In this, Jones (1777) is relevant since it concerns defrauding the Crown, via an army paymaster. Treeve (1796), however, is an example of the offence of supplying unwholesome food to the public. Such an offence was committed whether the supplier was a Government contractor or not. Thus, Treeve does not directly relate to cheating the public revenue - although it was often cited by subsequent legal writers in that context.

\section{Russell (1819)}

\section{(a) Russell}

Russell - in the first edition of his text On Crimes and Misdemanours, in $1819^{264}$ - considered cheats in general (the law on this is no longer relevant). ${ }^{265}$ Then, after considering cheats which are 'levelled against the public

\footnotetext{
257 Ibid.

${ }^{258}$ Cornwall, Summer Assize 1796 (unreported). For an early precedent to this see Riley, n 162, pp 536-7. On 27 June 1394, one William Whitman was brought before the Mayor and Aldermen of the City of London for selling to a merchant old roots and rotten powders for good powdered ginger and other worthless material for genuine wormseed (artemisia santonica). A jury held him guilty of deceit and falsehood. He was placed in the pillory. The material was burnt.

${ }^{259}$ See also Turner, n 17, vol 2, pp 1157-8.

${ }^{260}$ East, $\mathrm{n} 247$, vol 2, stated, p 822 'The defendant...was in fact a contractor with the government for the supplying of provisions to the French prisoners in the neighbourhood of Plymouth in the course of the then war; though that was not stated in the indictment on which the conviction took place. Nor was it material so to state it, otherwise than as a matter of aggravation if such a case wanted any: for the giving of any person unwholesome victuals not fit for man to eat, lucri causa, or from malice or deceit, is undoubtedly in itself an indictable offence, apart from any other consideration, which entered deeply into the demerits of the defendant's conduct.' (italics supplied)

${ }^{261}$ Coventry Lent Assizes, 1777 (reported).

${ }^{262}$ East, n 247, vol 2, p 822.

${ }^{263}$ Ibid, pp 826-7.

${ }^{264}$ Russell n 13. For a useful summary see also, R Burn (ed G Chetwynd), The Justice of the Peace and Parish Officer (London, 1820), vol 1, pp 467-80 (Cheat). Burn treated embezzlement as part of cheat.

${ }^{265} \mathrm{Ibid}$, vol 2, p 1360 'Where the possession of goods is obtained, in the first instance, without fraud, upon a contract or trust, a subsequent dishonest conversion of them, while the privity of contract continues undetermined, will only be a breach of trust or civil injury, and not the subject of a criminal prosecution. But where the party obtaining the goods has recourse to fraudulent means in the first instance, and thereby succeeds to the extent of inducing the owner not only to deliver the possession of the goods to him, but absolutely to part with the property in them, though such a taking will not, as we have seen be considered as felonious and amounting to larceny; yet if effected by means of a false token, or a false pretence, it will come within the provisions of certain statutes, and be punishable as a misdemeanour. Besides the statutes also which relate to such offences, the common law provides for the punishment of many of those cheats and frauds which may affect the public
} 
justice of the kingdom' which were 'indictable at common law', ${ }^{266}$ Russell continued:

Those frauds which affect the crown and the public at large, are also clearly the subject of indictment, though they may arise in the course of some particular transaction or contract with private individuals. Amongst offences of this description, is the selling of unwholesome provisions. And it is said, more largely, that the giving of any person unwholesome victuals, not fit for man to eat, lucri causa, or from malice or deceit, is undoubtedly, in itself, an indictable offence. ${ }^{267}$

In respect of the latter, Russell cited Treeve (1796). ${ }^{268}$ Russell then stated:

In some cases the rendering false accounts and other frauds practised by persons in official situations, have been deemed offences so affecting the public as to be indictable. Thus, where two persons were indicted for enabling persons to pass their accounts with the pay office in such a way as to enable them to defraud the government; and it was objected that it was only a private matter of account, and not indictable; the court held otherwise, as it related to the public revenue. ${ }^{269}$ [ie. Bembridge]

And instances appear in books of indictments against overseers of the poor for refusing to account, pursuant to a statutory duty to do so. The court held that their refusal to do so was a contempt of the law for which they might be indicted for a cheat. ${ }^{270}$ [ie. Commings]

And a precedent is given of an indictment [in 1799] against a surveyor of the highways (from the Crown Office) for converting to his own use gravel which had been dug at the expense of the inhabitants of the parish, and also employing for his own private gain and emolument the labourers and teams of the parishioners, which he ought to have employed in repairing the highways. ${ }^{271}$ [ie. Robinson] (wording divided for ease of reference).

Russell also referred to Jones (1777) (see 14(b)) observing that such an offence was now punishable under the Mutiny Acts. ${ }^{272}$

\section{(b) $\underline{\text { Hawkins - Last Edition }}$}

It may also be noted that the last edition of Hawkins (1824) closely followed East. It stated:

So it is said all frauds affecting the crown and public at large are indictable as cheats at common law, as in the following case...

Hawkins then referred to Treeve (1796) as well as to Jones (1777), citing East. ${ }^{273}$ Thus, the source for the modern proposition on cheating the public revenue is actually East (in 1803) and not Hawkins ${ }^{274}$ - although subsequent writers (and the courts) have tended to present Hawkins as the source, when this is not so.

In conclusion, the primary decisions which Russell cited in respect of cheating the public revenue were Bembridge (1783) and Jones (1777). The last edition of Hawkins then adopted the general propostion of East, re-casting it slightly.

\section{Gabbett (1843), Harris (1881), Stephen (1883)}

As to later legal writers and their commentary on the law of cheat, Gabbett - in his Treatise on Criminal Law in 1843 - had a chapter 'Of Cheats'. ${ }^{275}$ He stated

welfare. It has been holden that, there must be a prejudice received, both at common law and under the statutes of 33 Hen VIII c 1 and 30 Geo II c 24. [see 9].'

${ }^{266}$ Ibid, pp 1361-2. Russell cited a number of the cases referred to by Hawkins, see 11.

${ }^{267}$ Russell cited East, see 14.

${ }^{268}$ Ibid, pp 1362-3. For Treeve (1796), see 14(b).

${ }^{269}$ Russell cited Bembridge, see $\mathbf{1 3 .}$

${ }^{270}$ Russell cited $R v$ Commings et al (1695) 5 Mod 179 (87 ER 594). However, it should be noted that this was a statutory duty to account (under 43 Eliz c 2, s 2 (1601) rep).

${ }^{271}$ Ibid, p 1366. Russell cited J Chitty, A Practical Treatise on the Criminal Law (London, 1826, $2^{\text {nd }}$ ed, 4 vols), pp 666-7. The indictment of 1799 stated that Robinson, a parish surveyor, 'not regarding his duty in that behalf, but minding and intending to promote his own private gain and emolument, at the expense of the inhabitants of the parish... unlawfully, wilfully and corruptly, by colour of his said office' did procure the gravel and labour on his premises.' There was also a count (the $7^{\text {th }}$ count) for embezzling the same.

${ }^{272}$ Russell, n 13, vol 2, p 1367.

${ }^{273}$ Hawkins, n 10, (1824), vol 1, p 322. J Gabbett, Treatise on the Criminal Law (Dublin, 1843), ch 12.

${ }^{274}$ Modern cases tend to cite Hawkins without realizing that he is simply repeating what East says.

${ }^{275} \mathrm{~J}$ Gabbett, Treatise on the Criminal Law (Dublin, 1843), ch 12. 
Several cases of malversation by public officers have been held to be indictable, as frauds and cheats of a public nature. Thus where Bembridge and Powell [1783] were indicted for enabling persons to pass their accounts with the pay office in such a way as to enable them to defraud the government, it was objected that it was only a private matter of account, and not indictable; but the court held otherwise, as it related to the public revenue. ${ }^{276}$

And in Tarrant's case [in 1767] an information was granted against an overseer of the poor of the parish of $\mathrm{H}$ for procuring a poor man of the parish of $\mathrm{W}$ to marry a single woman with child of a bastard, in order to get the bastard settled in the parish of $\mathrm{W}$ where the husband was settled, and thus relieve his own parish from the burden of maintaining the pauper, and throw it on the other. ${ }^{277}$

And a precedent may be referred to [Robinson, in 1799] of an indictment against a surveyor of the highways for converting to his own use gravel which had been dug at the expense of the inhabitants of the parish, and also employing, for his own private gain and emolument, the labourers and teams of parishioners, which he ought to have employed in repairing the highways. ${ }^{278}$

And it is general principle that all frauds affecting the crown and the public are indictable though arising out of a particular transaction or contract with the party. And upon this principle apprentices have been held to be indictable, who enlist without the consent of their masters; such apprentices, at the time of receiving the bounty or enlisting money, knowing themselves to be disqualified from serving as soldiers without such consent, and thereby defrauding the $\operatorname{king}^{279} \ldots$.. [ie. Jones] (wording divided for ease of reference) ${ }^{280}$

Harris - in his Principles of the Criminal Law in 1881 - did not deal with defrauding the revenue as such. ${ }^{281}$ Sir James Fitzjames Stephen, in his Digest of the Criminal Law in 1883, ${ }^{282}$ defined 'cheating' (art 338) ${ }^{283}$ but did not deal with cheating the public revenue. ${ }^{284}$

In conclusion, Gabbett dealt with cheating the public revenue, Harris and Stephen did not.

\section{Bradbury \& Edlin (1920), J (1933)}

\section{(a) Bradbury \& Edlin (1920)}

In this case ${ }^{285}$ - one which effectively revived the offence of cheating the public revenue after Bembridge (1783) - the defendant was charged with:

- Conspiracy to cheat and defraud the king of money due in respect of income tax, excess profits duty and super tax by making false statements and returns;

- Making false statements in returns of income tax contrary to the Perjury Act 1911, s 5(b) ${ }^{286}$ and;

\footnotetext{
${ }^{276}$ Gabbett cited East. See 14.

2774 Burr 2106 (98 ER 99)(Information granted against an overseer for improper conduct).

${ }^{278}$ See n 271 (Robinson's Case).

${ }^{279}$ Reference was made to Jones (1777), see 14(b).

${ }^{280}$ Gabbett, n 275, p 204.

${ }^{281}$ SF Harris, Principles of the Criminal Law (Stevens \& Haynes, 1881), pp 238-9, 'Cheating is a comprehensive term, including in its wider signification false pretences, false personation, and other crimes which are specially provided for. A cheat at common law is the fraudulent obtaining the property of another by any deceitful and illegal practice or token which affects or may affect the public. Thus, the leading characteristic of such a cheat is the publicity of its effects. Therefore, a cheat or fraud effected by an unfair dealing and imposition on an individual is not the subject of an indictment at common law. Of course many acts of cheating are not punishable at all by the common law; the person wronged being left to its remedy by civil action. The chief offences regarded as cheats at common law are the following - Against public justice e.g.counterfeiting a discharge. Against public health e.g. selling unwholesome provisions. Against public economy e.g. by using false weights or measures. There must be a plausible contrivance, as in the last instance, against which common prudence could not have guarded. Thus, though selling by false weights or measures is a misdemeanor, selling under weight is merely actionable.'

${ }^{282}$ JF Stephen, A Digest of the Criminal Law (Macmillan \& Co, $3^{\text {rd }}$ ed, 1883), p 272.

${ }^{283}$ Ibid (art 338). 'Every one commits the misdemeanor called cheating, who fraudulently obtains the property of another by any deceitful practice not amounting to felony, which practice is of such a nature that it directly affects, or may directly affect, the public at large. But it is not cheating within the meaning of this article to deceive any person in any contract or private dealing by lies unaccompanied by such practices as aforesaid.' There was a separate article to deal with cheating at play, see art 333.

${ }^{284}$ He treated Treeve (1796), see 14(b), as an example of cheating, but not in relation to the revenue. One would assert this is correct.

${ }^{285}$ [1956] 2 QB 262, note. This was a case at the Winchester Assizes in 1920. The decision of the Criminal Court of Appeal affirming the decision of Bray J was reported in [1921] 1 KB 562 (it dealt with the Perjury Act 1911, s 5(b)).

${ }^{286}$ The section (still extant) is entitled 'False Statement, Declaration and Other False Statements without Oath.'
} 
- Delivering false returns tending to prejudice the king and the public revenue with intent to defraud the king contrary to the common law.

Of the charges laid at common law, 5 were alternative charges to those laid under the Perjury Act 1911 and two related to the submission of false trading and profit and loss accounts of the business of a company of which both the defendants were directors. Bray J, after dealing with the statutory position, considered the common law offence. He stated:

There are other counts charging them with the offences under the common law. Count 3 is an instance, in which the defendants are charged with making a false statement with intent to prejudice the public revenue contrary to the common law, and then it gives particulars of the offence. It is said that that is not an offence known to the law, that it is not within the common law of England. It certainly struck me, when the argument was made, that if it was not an offence it was quite time that it was made an offence.

But the common law of England is based on common sense, and it seems to me to be eminently in accord with common sense that when a person commits an offence of this kind, and makes a false statement with a view to prejudicing his Majesty's revenue, it ought to be punishable...In my view it is an indictable offence because it comes within the class of case of which one or two have been cited today. ${ }^{287}$

All these cases affecting the Crown and the public at large are indictable, and in my opinion, therefore, these common law counts stand, save for one other argument. By s 178 of the Income Tax Act 1842 it is provided that if there is such a fraudulent representation a certain penalty is provided... It is suggested that because there was an additional penalty imposed upon persons who offended against the Act, in their having to pay treble the duty evaded, that that repealed the common law of England.

In my opinion it certainly did not. It added an additional burden or obligation if you like, but it never did take away the right to proceed against an offender by indictment under the common law of England, and therefore these objections fail, and the defendants must proceed. ${ }^{288}$ (wording divided for ease of reference)

\section{(b) $\underline{\operatorname{Rex} v ~ J ~(1931)}$}

This was a Northern Ireland case. ${ }^{289}$ An indictment against the defendant for defrauding the Revenue alleged that he - unlawfully, with intent to defraud and to the prejudice of the king and the Commissioners of Inland Revenue - delivered to the latter a return for the assessment to super tax falsely stating his total income from all sources, less charges, which figure was false since the actual figure largely exceeded that sum which he well knew at the time and he did so falsely pretend. There were 5 similar counts for subsequent years. The defendant contended there was no such offence at common law. However, the indictment was held good.

- Counsel for the Crown referred to: Treeve (1796), Bembridge (1783), Jones (1777), Bradbury (1921)(see 13, 14(b) and 17(a));

- He also referred to Munton (1793) ${ }^{290}$ and Higgins (1801); ${ }^{291}$

- Counsel also cited $R v$ Brailsford (1905) ${ }^{292}$ and $R v$ Carlile (1819) ${ }^{293}$ which were of no direct relevance.

\footnotetext{
${ }^{287}$ Treeve (1796) and Bembridge (1783) were cited. Also East, see 14.

${ }^{288}$ At pp 263-4.

${ }^{289}$ (1931) Northern Ireland Law Reports 73. The trial was before Andrews LJ presiding at the Belfast City Commission.

${ }^{290}$ The defendant was a storekeeper in Antigua in the West Indies. The principal charge on which the information was founded was that he had purchased, in England, certain stores at a nominal price. On this price (which had been arranged between him and the seller) he had received a considerable allowance, which allowance he took for his own use, by which the Government was defrauded to a considerable extent. The case mainly concerned whether the court of King's Bench had jurisdiction. The defendant was found guilty. The offence being of a very serious nature, D was remanded. A note provided that 'the sentence of the court has not yet been pronounced.'

2912 East 5, 21 (102 ER 269). The case concerned the soliciting of a servant to steal from his master. However, obiter, Lawrence J, at p 21, stated that 'all offences of a public nature, that is, all such acts or attempts as tend to the prejudice of the community, are indictable.'

292 [1905] 2 KB 730. An indictment against two defendants for conspiracy alleged that they had unlawfully conspired to obtain a passport in the name of one of the defendants from the Foreign Secretary by falsely pretending and representing that that defendant desired to use th passport himself while travelling in Russia with intent that the passport should be used by another person in the name of that defendant, and that the defendants in pursuance of the conspiracy sent the passport to the other person for use by him in Russia, in fraud of the Foreign Office regulations for the issue of passports, to the injury and prejudice and disturbance of the lawful, free and customary intercourse between the subjects of the king and those of the Czar of Russia, to the public mischief of the subjects of the king, and to the endangerment of the continuance of the peaceful relations between the king and the Czar and their subjects respectively. It was held that the indictment was good.
} 
In the case, Andrews LJ stated:

In my opinion, it is a common law offence to defraud the king of his revenue. It has always been a misdemeanour to make a false statement for the purpose of depriving the king of any part of his revenue; and making deliberately a false return for the purpose of defrauding the revenue is, merely, what I may call a modern illustration of that principle. It is an offence under the common law, quite apart from any created by Act of Parliament. ${ }^{294}$

As to whether the Income Tax Act 1918, s 224 (which prescribed a penalty) had taken away by statute any common law offence, in so far as it related to the making of false returns for revenue purposes, Andrews LJ stated:

It has been argued that statute cannot take away the right of the king at common law. In my opinion, not only has the right not been taken away, but it has been expressly preserved. I say this for two reasons. In the first place that is not a new offence created by statute; and, therefore, when we find that a remedy is provided in the Finance Acts, the king is not thereby deprived of his remedy at common law. The second reason for my opinion is founded on the express words in section 224 of the Income Tax Act, 1918, which provides that the provisions of that Act 'shall not affect any criminal proceedings for any felony or misdemeanour'. Therefore, no enactment which provides for the imposition of treble charge or for power to have the matter considered at petty sessions, in any way interferes with the common law rights of the king. The opinion I have expressed is in accordance with the decision of Bray $\mathrm{J}$ in Rex $v$ Bradbury \& Edlin...(see 17(a)). ${ }^{295}$

In conclusion, Bradbury and Edlin as well as Rex $v J$ confirmed that the offence of cheating the public revenue existed at common law. This is unsurprising since this offence existed - at least - in 1376 and, indeed, prior to that.

\section{Cross and Jones (1949), Harris (1950)}

Cross and Jones - in their Introduction to Criminal Law, the second edition of which was in 1949 - did not deal with cheating the revenue or, indeed, discuss cheating in any detail. ${ }^{296}$ Nor did Harris, in the eighteenth edition of the work in 1950. ${ }^{297}$ Smith and Hogan - in the first edition of their Criminal Law in $1965{ }^{298}$ - stated:

Cheating is a misdemeanour at common law ${ }^{299}$ and is punishable by imprisonment. ${ }^{300}$ The offence was developed most vigorously during the eighteenth century and when the authorities are examined it immediately becomes clear that it needs a large and liberal definition to encompass them all. ${ }^{301}$

They went on to analyse: (a) personation; (b) selling food unfit for human consumption ${ }^{302}$ and (c) defrauding by means of false tokens and devices. Finally, they stated:

\footnotetext{
2933 B \& Ald 161, 163 (106 ER 621). It was held that a statute ( 9 \& 10 Will 3 c 32 (1697), rep) had not altered the common law as to the offence of blasphemy but only given a cumulative punishment. Abbot CJ stated at p 163, 'Now I take it to be a general rule, that where there is a misdemeanour at common law, a statute providing a particular punishment for it does not repeal the common law.' See also Best J, at p 165 'It has long been a settled maxim, that neither the provisions of the common or statute law are abrogated but by the express words of an Act of Parliament, or by subsequent enactments, so inconsistent with the previous law as to raise a necessary implication that the legislature intended it should be altered.'

${ }^{294}$ At $\mathrm{p} 78$.

${ }^{295}$ Ibid. A note states 'The trial of the defendant accordingly proceeded after Andrew LJ had delivered judgment, and resulted in the disagreement of the jury.'

${ }^{296}$ Cross \& Jones, Introduction to Criminal Law $\left(2^{\text {nd }}\right.$ ed, 1949). CS Kenny, Outlines of Criminal Law (Cambridge UP, $2^{\text {nd }}$ ed 1904) dealt with false pretences (ch 15), but not cheating the public revenue.

${ }^{297}$ Harris, n 281 (1950 ed) simply observed, at p 340, 'A public cheat is an indictable misdemeanour at common law and consists in the use of some fraudulent device either: (i) to prevent the administration of public justice; or (ii) to induce the owner of goods or money to part with his property in them. In the case of a cheat against a private individual it is necessary to prove that the act has been completed and that there has been an injury to the individual: in the first class of cases, however, neither of these elements is essential and therefore the mere preparation of false evidence to mislead a tribunal is a misdemeanour, even though the evidence is not used.'

298 JC Smith \& B Hogan, Criminal Law (1 $1^{\text {st }}$ ed, 1965).

${ }^{299}$ They noted 'It was also a statutory offence of some antiquity. The statute $33 \mathrm{Hen} 8 \mathrm{c} 1$ (see 9) made it an offence to obtain money or chattels by the use of false tokens or counterfeit letters.'

${ }^{300}$ They cited the Criminal Procedure Act 1851, s 29.

${ }^{301}$ Smith \& Hogan, n 298, p 46.

302 They cited Treeve (1796) (see 14) and noted 'This form of cheating has now, of course, been supplanted by statute', referring to the Food and Drugs Act 1955, s 8 (an offence punishable with a fine and imprisonment to sell food unfit for human consumption).'
} 
Other instances, such as false accounting by a public officer and frauds in connection with enlistment, are now covered by other statutory provisions, but one instance which is very much alive appears from Hudson [see 19]. Here the Court of Criminal Appeal upheld D's conviction on a charge of making false statements to the prejudice of the Crown and the public revenue with intent to defraud, where it appeared D had falsely stated to the Inland Revenue the profits of his business. It was argued that the indictment disclosed no offence known to law, but the court, relying on dicta of Lord Mansfield CJ, in Bembridge, and statements by Hawkins and East held that it was an offence for a private individual, as well as a public officer, to defraud the Crown and the public. ${ }^{303}$

In conclusion, Smith and Hogan considered cheating the public revenue. However, Cross and Jones and Harris did not.

\section{Hudson (1956) ${ }^{304}$}

A taxpayer was convicted on 8 counts of an indictment charging him with making false statements to the prejudice of the Crown and the public revenue with intent to defraud. ${ }^{305}$

- The indictment alleged that he caused to be submitted to an income tax inspector, with intent to defraud, accounts showing the profits of his business over a number of years to be substantially less than they, in fact, were and by delivering to the inspector a certificate of disclosure of facts relating to his tax liability which was false, to his knowledge;

- The casenote noted that the facts disclosed a fraud on the sovereign and that a fraud by an individual on the sovereign or the public (which were synonymous terms) was an indictable misdemeanour at common law. Also, that the taxpayer - by sending to the inspector of taxes documents which were false and fraudulent to his knowledge for the purpose of avoiding the payment of tax - had defrauded the Crown and the public and was, therefore, properly, convicted of the offences charged.

Giving judgment, Goddard CJ summarised the basic nature of the offence of which the defendant was accused:

We think that the offence here consisted of sending in documents to the inspector of taxes which were false and fraudulent to the defendant's knowledge. That is a material part of the offence, and the jury found it proved. ${ }^{306}$

Noting that such an offence of cheating was not expressly mentioned in the Income Tax Acts or the Perjury Act 1911, ${ }^{307}$ Goddard CJ cited Hawkins ${ }^{308}$ where the latter stated 'all frauds affecting the Crown and the public at large are indictable as cheats at common law'. He also cited East, 'All frauds effecting the Crown and public at large are indictable, though arising out of a public transaction or contract with the party. ${ }^{309}$ Goddard CJ also referred to Bembridge (1783) stating:

That is the clearest possible statement by a great master of the common law that a fraud on the public by an individual is indictable, although the particular fraud might not have been indictable if it had been a fraud by one subject upon another. ${ }^{310}$

Goddard CJ also referred to to $R v J$ (1933) ${ }^{311}$ and to Bradbury and Edlin (1920)(see 17) stating, as to the latter:

the same objection was taken before Bray J...where, on an indictment in the form used here (which had

\footnotetext{
${ }^{303}$ Smith \& Hogan, n 298, p 429.

${ }^{304}$ [1956] 2 QB 252.

${ }^{305}$ Counsel to the Crown noted, p 257 'This charge has been laid in over 100 cases since the year 1917, when it was laid for the first time. Of the convictions obtained, six were before the decision in Rex v Bradbury, 25 between the date of that decision and 1946, and 69 since 1946, the cases being heard before 28 different judges of the High Court. Only in five cases has the point now argued by the appellant been taken, in none successfully.' [the point was that, no one looking at the indictment would see a reference to common law cheating. The indictment was applicable to specific offences, namely, causing the inland revenue to be defrauded.'].

${ }^{306}$ At p 261. Also, p 258 'If a trader says that he has made a full disclosure when he knows full well that he has not, then he is acting fraudulently.'

${ }^{307}$ At p 259 'because, I suppose, it was overlooked that traders sometimes send in accounts instead of including a specific amount in the return.'

${ }^{308}$ Ibid 'a work of the highest authority which has been cited in the courts for many years' The edition Goddard CJ cited was the 8th ed (published in 1824), vol 1, p 322.

${ }^{309}$ See 14.

${ }^{310}$ At $\mathrm{p}$ 260. Goddard CJ also noted that: 'It does not appear that he [i.e. Bembridge] had gained anything from it, but he did it and did it fraudulently, as the jury found.'

${ }^{311}$ Goddard CJ quoted Andrews LJ, second paragraph, see 17(b).
} 
then been used by the Board of Inland Revenue for some two or three years), Bray J held, without any hesitation apparently, that the facts disclosed a common law misdemeanour. This form of indictment has been used ever since by the Board of Inland Revenue where the offence charged is that of submitting false accounts. It has been challenged once or twice, but it has never been challenged after conviction by being brought up to this court. It seems to me perfectly clear that the communis opinio among lawyers has been that Bray J's decision was right, and I cannot see any ground upon which we can say that the authorities upon which he acted, and upon which we are acting today, have ever been limited or dissented from. In Northern Ireland the the same view was taken by in $\operatorname{Rex} v$ ' $J$ '... and it has never been in any way dissented from there. ${ }^{312}$

In conclusion, Hudson upheld the existence of the common law offence of cheating the public revenue.

\section{Turner (1964), Kenny (1966)}

The last edition of Russell, On Crime, edited by Turner in 1964, considered, in a chapter, the law on cheats, frauds, false tokens and false pretences. ${ }^{313}$ As to cheats, it noted:

At common law many cheats and frauds affecting the public welfare and causing an actual prejudice are indictable. ${ }^{314}$

Turner then discussed: (a) cheats levelled against public justice; (b) frauds which affected the Crown and the public at large, although they might arise in the course of some particular transaction or contract with private individuals $;^{315}$ and (c) the selling of unwholesome provisions. Finally, he stated:

In some cases the rendering of false accounts and other frauds practised by persons in official situations have been deemed offences so affecting the public as to be indictable. Thus, where two persons were indicted for enabling persons to pass their accounts with the pay office in such a way as to enable them to defraud the government, and it was objected that it was only a private matter of account and not indictable, the court held otherwise, as it related to the public revenue. ${ }^{316}$ [ie. Bembridge] There are precedents of indictments against overseers of the poor for refusing to account, ${ }^{317}$ [ie Commings] and for rendering false accounts and of an indictment against a surveyor of highways for converting to his own use gravel dug at the expense of the parish, and for employing for his own private gain and emolument the labourers and teams of the parishioners which he ought to have employed in repairing the highways. ${ }^{318}$ [ie Robinson]

Although this text did not refer to Hudson and other cases, Turner - in the final edition of Kenny's Outlines of Criminal Law in 1966 - had a chapter on 'Cheats Punishable at Common Law' ${ }^{319}$ In respect of cheats practised on the public, he stated:

Where, however, the dishonest activity was of a sort which aimed at defrauding such members of the public as a whole who might come within its reach, then because of its generally injurious character it was treated by the common law as a crime (although only in the degree of a misdemeanour), in any instance in which any particular member of the public suffered by it. False statements without more were held not to be enough, and some misleading device in a permanent form was needed, such as false weights, measures, trade-marks, loaded dice, marked playing cards or even unwholesome food. Thus in the case mentioned in the preceding paragraph, the court stated that it was 'not indictable unless he came with false tokens; playing with false dice is, for that is such a cheat as a person of ordinary capacity cannot discover'.

In $R v$ Hudson [see 19] the Court of Criminal Appeal upheld the conviction of the appellant on a charge of making false statements to the prejudice of the Crown and the public revenue with intent to defraud by causing to be submitted to an inspector of income tax with intent to defraud a false certificate of disclosure: the court held that a fraud on the sovereign or the public (which were synonymous terms) was

\footnotetext{
${ }^{312}$ At $\mathrm{p} 261$.

313 Turner, n 17, ch 70 .

${ }^{314}$ Ibid, at p 1155.

315 Turner discussed Brailsford, see n 292.

316 Turner cited Bembridge, see 13. Also. East, see 14.

317 Turner cited Commings, see n 270.

318 At pp 1158-9. As to the case in 1799, see n 271.

319 JWC Turner (ed), Kenny's Outlines of Criminal Law (Cambridge UP), ch 16.
} 
an indictable misdemeanour at common law. ${ }^{320}$

Turner also noted that:

Numerous cases which were formerly treated as common law cheats are now more conveniently dealt with under more specific heads owing to developments in the law by statute or by an increased particularity in the common law itself, for example by the development of the law of forgery. ${ }^{321}$

In conclusion, Turner considered the offence of cheating the public revenue, mainly with reference to Bembridge and Hudson.

\section{Mavji (1987)}

In this case, ${ }^{322}$ the appellant conducted a large scale traffic in gold by three different types of transaction and at prices which would have inevitably produced a loss but for the fact that he had charged VAT but had not accounted for it to the Customs \& Excise. He was convicted of the offence of cheating the public revenue.

- An appeal was made on the basis that deception was a necessary ingredient of the offence. It was held the common law offence did not necessarily require a false representation - either by words or conduct. Cheating could include any form of fraudulent conduct which resulted in diverting money from the public revenue and depriving it of money to which it was entitled;

- The appellant, in the circumstances, had a statutory duty to make VAT returns and to pay over to the Crown the VAT due. He had done neither. Therefore, he was guilty of cheating the Crown and the public revenue. No further act, or omission, was required to be alleged or proved.

Two principal submissions were made. One was that the Finance Act 1972, s $38(1)^{323}$ also covered the situation. A submission was made that it would be anomalous if the common law and statutory offences stood side by side, with no more having to be proved to establish the former than the latter and, in the former case, without limit of penalty. Michael Davies J stated:

We see no anomaly. In our judgment section 38(1) of the Finance Act 1972 was a 'catch-all' provision directed specifically to punish evasion of VAT when that tax was newly introduced and has no bearing on the general principles of cheating in relation to the Public Revenue, particularly as there is no counterpart to section $38(1)$ in the statutory provisions relating to other taxes. ${ }^{324}$

It was also submitted that deception was an ingredient of the common law offence. After being referred to various authorities, ${ }^{325}$ Michael Davies J stated:

in none of the cases or authorities such as Hawkins is the distinction between 'deceit' involving a general act and 'non-deceit' involving no more than an omission canvassed or regarded as vital or indeed relevant. The distinction has always been and in our view remains between 'frauds affecting the Crown and public at large'... and those which affect only individuals. ${ }^{326}$

In conclusion, Mavji held that deception was not a pre-requisite for the offence of cheating the public revenue. Also, the fact that a statutory offence also existed did not preclude the common law offence. The first proposition was unsurprising since cheating the public revenue is a misprision.

\section{Redford (1988) ${ }^{327}$}

This case was very similar to Mavji (1987). The appellant was the proprietor of a motor trade business dealing

\footnotetext{
${ }^{320}$ At $\mathrm{p}$ 352. Turner went on to consider false pretences made to private individuals.

${ }^{321}$ Turner cited the Weights and Measures Acts 1878-1963, the Merchandise Marks Acts 1887-1963, the Copyright Act 1956 and the Larcency Act 1916, s 32 .

322 (1987) 84 Cr App R 34.

${ }^{323}$ It provided that 'If any person is knowingly concerned in, or in the taking of steps with a view to, the fraudulent evasion of tax by him or any other person, he shall be liable to a penalty of $£ 1000$ or three times the amount of tax, whichever is the greater or to imprisonment for a term not exceeding two years or both.' At p 37 per Michael Davies J 'So a statutory offence, the fraudulent evasion of VAT is created, with maximum penalties.'

${ }^{324}$ At p 38. See also Revenue \& Customs Commissioners v Total Network SL [2008] UKHL 19 [136] (proposition that statutory offences co-exist with the common law offence of cheating the public revenue confirmed).

${ }^{325}$ Reference was made to Hudson (see 19), to Hawkins, to Bembridge (see 13), to Bradbury \& Edlin and to Rex v J (see 17). Also, to Tonner [1985] 1 WLR 344, 351 in which Watkins LJ, obiter, dismissed an appeal that the offence of cheating the public revenue required proof of a positive act. See also Law Commission, Criminal Law: Conspiracy to Defraud (HMSO, 1994), para 3.3.

${ }^{326}$ At $\mathrm{p} 38$.

327 (1988) 89 Cr App R 1.
} 
with the buying, repairing and re-selling of motor vehicles. He admitted he had failed to register for VAT or to pay any.

- He was charged with contravening the Finance Act 1972, s 38(3) and the VAT Act 1983, s 39(1). It was sought to amend the indictment in order to charge the appellant with the common law offence of cheating the public revenue (this was granted);

- On appeal, the appellant argued that: (a) the common law offence was not available when the facts showed that a statutory offence had been committed; and (b) the common law offence required some positive act of deception directed at the public revenue. Mere omission, or failure to act, was not enough.

The court held that the Theft Act 1968, s 32(1) should be given its plain meaning. Thus, the common law offence still existed and was indictable whatever statutory offences might be available on the facts. Further that the common law offence was satisfied by a matter of omission in the present case.

- The court followed Mavji, holding that the point there was 'almost precisely on all fours.' ${ }^{328}$ It also cited Bembridge (1783) which it described as the 'locus classicus of the offence of cheating the Public Revenue,; 329

- The court held that the failure of the appellant to register for VAT and to make the requisite returns and payments to the Commissioners of Customs and Excise was sufficient to constitute the offence.

In conclusion, Redford held that the common law offence existed. Further, omission, as well as commission, was sufficient to comprise the offence. The first proposition was unsurprising since cheating the public revenue is a misprision.

\section{Mulligan (1990), Less (1993), Hunt (1994)}

\section{(a) Mulligan (1990)}

In this case ${ }^{330}$ from company premises, there was stolen: (a) a certificate of exemption from income tax used by sub-contractors in the construction industry (form 714); and (b) a book of vouchers acknowledging gross money received by an exempted sub-contractor (form 715).

- The stolen form 714 was found concealed in M's clothing (he said that he had received it from another person, W). M also acknowledged he had acquired the book of form 715 vouchers and left it at the house of a third party while looking for buyers of the vouchers;

- M was charged with conspiring (with W) to cheat Her Majesty the Queen and the public revenue, going equipped to cheat, handling and theft.

A submission was made that the common law offence was not known to the law. It was rejected on the basis, in particular, of Hudson (see 19) and Redford (see 22).

\section{(b) $\underline{\text { Less (1993) }}$}

This unreported case ${ }^{331}$ concerned the dishonest withholding of PAYE and National Insurance payments. The trial judge stated:

The common law offence of cheating the public revenue does not necessarily require a false representation either by words or conduct. Cheating can include any form of fraudulent conduct which results in diverting money from the revenue and in depriving the revenue of the money to which it is entitled. ${ }^{332}$ It has, of course, to be fraudulent conduct. That is to say, deliberate conduct by the defendant to prejudice, or to take the risk of prejudicing, the Revenue's right to the tax in question, knowing that he has no right to do so.

One would agree with the first sentence since the offence of defrauding the revenue is a misprision and, thus, can occur by way of omission or commission. Therefore, deception, or any other active form of misrepresentation, is

\footnotetext{
${ }^{328}$ At $\mathrm{p} 7$.

${ }^{329}$ Ibid, p 8.

${ }^{330}$ [1990] Crim LR 427.

331 The Times, $30^{\text {th }}$ March 1993. See also Ormerod, n 28, p 629.

${ }^{332}$ Cf. Ormerod, $\mathrm{n} 28, \mathrm{p}$ 629, fn 17 'The reference to money being diverted from the Revenue is, it is submitted, unnecessary, since it is clear that no loss need actually arise.' One would agree.
} 
not required. ${ }^{333}$ One would disagree with the second sentence. Being a misprision, loss is not a pre-requisite. It is the conduct (the 'contempt') which is punished, not the consequence. One would agree with the third sentence. To 'cheat' is the same as to defraud, just as the earlier Anglo-Norman word 'deceite' is the same as fraud.

\section{(c) Hunt (1994)}

In this case, ${ }^{334}$ the appellant appealed against his conviction of conspiring to cheat the Inland (Public) Revenue on the basis that loss had to be proved. This was dismissed, on the basis that there was ample authority to show from the cases ${ }^{335}$ - that cheating the public revenue was a conduct offence and that no loss had to be proved. One would agree, the offence being a misprision.

\section{(d) Ryan (1994)}

The appellant were tried for cheating the public revenue for dishonestly failing to pay VAT on the takings of gaming machines. The defence sought to quash the indictment on the basis that the VATA 1983, sch 6, group 4, note 1(d) (a proviso excluding gaming machines from exemption) was incompatible with the Sixth Council Directive (771/388/EC). This was rejected. ${ }^{336}$

In conclusion, in Mulligan, the existence of the common law offence was upheld. In Hunt, it was established that proof of loss was not a pre-requisite for the offence. The latter proposition was unsurprising since cheating the public revenue is a misprision.

\section{Summary of the Law}

From a review of the law from the earliest times, the following would seem clear:

Defrauding the Public Revenue. From, at least, the Laws of Henry I (c.1113) it was an offence not to pay tax (Danegeld) when duly levied. The punishment was a fine payable to the Crown (wite). Also, unlawful appropriation of the sovereign's money was reserved to the Crown and was punishable as theft Matters to be inquired at by justices at Eyre cited by Bracton (c. 1240) and Britton (c. 1290) included various revenue offences. The punishment was usually a fine - as well as loss of land, loss of office and imprisonment in some cases;

Public Revenue. In early times, the reference would have been to the Crown and, more particularly, that part of the Crown which comprised the Exchequer (today, called the 'Treasury') ) $^{337}$ to which all sums had to be paid in person, on oath. Thus, 'Public Revenue', today, means only sums paid in to the Treasury and not to a wider concept of 'public' revenue, ${ }^{338}$

Cases. The Selden Society Reports cite various examples of persons punished for defrauding the public revenue. Further, since, at least, Gaveston (1307)(see 7) important persons were punished for High Crimes and Misdemeanours by Parliament, which included revenue offences;

Nomenclature. In early times, the Anglo-Norman word often employed to cover fraud was 'deceite'. This word was replaced in $17^{\text {th }}$ century legal citations by the thieves' canting word 'cheat'. However, the two meant the same. Today, the legal word 'cheat' still means the same as fraud. Thus, 'Cheating the Public Revenue' is the same as 'Defrauding the Public Revenue;'

Misprision \& Loss. Like the offence of misconduct in a public office, cheating the public revenue was a misprision. Misprisions can occur be by way of omission as well as by commission. Further, misprisions do not require proof of loss, nor deception;

Hawkins - Confusion. The legal writer Hawkins - in the first edition of his text on Pleas of the Crown (in 1716-21) - analysed the offence of cheat. In so doing, he packaged together many offences which derived (in the main) from City of London offences in respect of the infraction of trade regulations such as for weights and measures, quality of goods (food, wine, clothing etc). Among the latter, it was

\footnotetext{
${ }^{333}$ In other words, the offence is committed as much where a person dishonestly supplies the Inland Revenue with a tax return containing inaccurate numbers as where a person dishonestly fails to submit a return. In both cases the Public Revenue (ie the Exchequer which, today, is called the Treasury) loses.

334 [1994] Crim LR 747.

335 Hudson was cited, see 19.

336 [1994] Crim LR 858. Reference was made to an unreported case of Feehan v Commissioner of Customs and Excise (2 ${ }^{\text {nd }}$ December, 1992).

${ }^{337}$ In early times the Exchequer was also called the Treasury. See also Fitzneale, n 64, p 6 (treasury in early times at Winchester as well as Westminster).

${ }^{338}$ See also Ormerod, n 28, pp 629-30.
} 
an offence to sell rotten (noisome) food. In 1803, the legal writer East, in the only edition of his text when writing on cheat - adopted many examples provided by Hawkins as well as cited the case of Treeve (1796). This case, however, is not one of cheating the public revenue. Rather, it is one of selling rotten food to the public (and would have been committed whether or not Treeve was a government contractor). Most of the cases cited by Hawkins and East were not relevant to cheating the public revenue (that is, the Crown). Rather, they related to cheating the general public which was quite different.

Cheating the Public Revenue. The locus classicus of this offence is Bembridge (1783). However, it was preceded by cases from much earlier times. Thus, the offence is long established. Cases which exemplify this offence are contained in Appendix A.

\section{Unnecessary Cases}

One of the problems of a large number of common law offences is that they are so old and so obscure, that, often, unnecessary cases are brought in respect of them, the original nature and scope of the offence being mis-understood. ${ }^{339}$ In the case of this offence the following may be noted:

- Existence of the Common Law Offence. The common law offence of cheating the revenue would seem to have existed at least, c 1113, long pre-dating modern income tax law (dating from 1798). The fact that tax legislation might stipulate similar penalties does not, per se, abolish any common law offence or penalty - the long established principle of interpretation being that the latter can only be abolished by express legislation, and not by implication. ${ }^{340}$ The assertion there was no offence at common law arose in Bradbury v Edlin (1920) where it was expressly rejected. However, the issue re-arose in Rex $v J$ (1931), Hudson (1956), Mavji (1987), Redford (1988) and Mulligan (1990);

- Omission. The common law offence was a misprision - which can occur by omission as well as commission. However, this issue was raised in Mavji (1987);

- Deception. The common law offence is one of fraud, which includes deception. However, deception is not a pre-requisite, since fraud is wider than deception. The words 'deceite' and 'cheat' referred to fraud, not just to deception. Whether deception was a pre-requisite was raised in Mavji (1987) and in Redford (1988). Further, deception is not required since the offence is a misprision and, thus, can occur by omission as well as commission;

- Loss. The common law offence is a misprision. Thus, there is no requirement that it be a pre-requisite that loss be proved. Further, common sense suggests various difficulties if it were. However, this issue was raised in Hunt (1994).

The Law Commission was founded in 1965. One criticism of it is that it has left to 'linger' many common law offences with the result that much unnecessary litigation has arisen, at great cost to the taxpayer. None of the above cases, post-Hudson (1965), should have occurred since the common law position was clear.

\section{A Statutory Offence}

The need for a statutory formulation of this offence would seem unarguable. However, the statutory offence can be, legitimately, wider than the modern caselaw suggests.

- $\quad$ Fraud on the Exchequer. In early times, it was, clearly, a fraud on the Exchequer to fail to pay - or use fraud to avoid paying - when owed, inter alia: (a) any tax (danegeld) and successor taxes; (b) any customs and excise (viz. prisage on wine and other prises); (c) any fines and amercements levied by the royal courts (see 4(a)). Thus, this situation should prevail today;

- Deception \& Proof of Loss. The statutory offence should not require as pre-requisites: (a) deception; (b) proof of loss. These never were pre-requisites of the offence in early times;

- Dishonesty. A pre-requisite of the offence has always been dishonesty. None of the caselaw indicates that oversight, unintentional error etc, was criminally culpable; ${ }^{341}$

\footnotetext{
339 Other examples are: (a) maintaining a bawdy house; and (b) misconduct in a public office.

${ }^{340}$ See n 293.

${ }^{341}$ It may be noted that the common law offence of conspiracy to defraud: (a) does not require deception; (b) requires dishonesty; (c) does not require causing (or taking) the risk of pecuniary loss; and (d) is based on an intent to defraud. See eg Law Commission, n 325, paras 2.3, 2.6 \& 2.11. It is appropriate this is so since the two offences are similar, save that cheating (defrauding) the public revenue is a misprision (therefore,
} 
- Fraud. A pre-requisite of the offence should also be fraud, which contains, implicit within it, both 'knowing' and 'dishonesty'. ${ }^{342}$ The word 'false' is not an appropriate word instead of fraud; ${ }^{343}$

- Defrauding the Public Revenue. The word 'cheat' means little today. So, too, the old Anglo-Norman word, 'deceite'. Instead, 'fraud' is the modern word - since both 'cheat' and 'deceite' meant exactly that. Thus, an offence of 'Defrauding the Public Revenue' accurately reflects to the public (and lawyers) the true nature of the offence;

- Public Revenue. This meant the Exchequer. Today, the Treasury. Thus, fraud vis-à-vis other public bodies was not (and, today, should not be) included.

Reference to 'fraud' also best dovetails with tax and customs and excise legislation. Thus,

- Income Tax: Finance Act 2000, s 144(1) (fraudulent evasion of income tax) makes it an offence if a person is ' $k$ nowingly concerned in the fraudulent evasion of tax [income tax] by him or another person. ${ }^{344}$ (This provision was repealed in 2010. However, it is cited here to indicate its reference to fraud and the word 'knowingly'); 345

- Tax Credits. Tax Credits Act 2002, s 35 (tax credits) makes it an offence if a person is "knowingly concerned in any fraudulent activity undertaken with a view to obtaining payments of a tax credit by him or any other person';

- VAT. VAT Act 1994, s 72 makes it an offence if a person is 'knowingly concerned in, or in the taking of steps with a view to, the fraudulent evasion of VAT by him or any other person' $;{ }^{346}$

- Customs \& Excise. Customs and Excise Management Act 1979, s 170 (2) (fraudulent evasion of duty) makes it an offence if a person 'knowingly acquires possession' of certain goods 'with intent to defraud' Her Majesty 'of any duty payable on the goods or to evade any such prohibition or restriction with respect to the goods;'

- Customs \& Excise. Customs and Excise Management Act 1979, s 50 (improper importation of goods) makes it an offence if a person 'with intent to defraud Her Majesty of any such duty or to evade any such prohibition or restriction' as mentioned.

\section{Formulation of a Statutory Offence}

A statutory offence might be as follows:

\section{Defrauding the Public Revenue}

1. It is an offence to defraud the public revenue.

2. A person defrauds the public revenue when a person, with intent to defraud, ${ }^{347}$ does not pay to the Crown any sum owed in respect of any:

(a) statutory tax; ${ }^{348}$

it can occur by omission) and is it limited to defrauding the public revenue. Thus, it is important that any statutory formulation of defrauding the public revenue is correctly aligned with the offence of conspiracy to defraud.

${ }^{342}$ See $A$-G's Reference No 1 of 1981 [1982] QB 848 where the Court of Appeal held that the term 'fraudulently' meant 'dishonestly and deliberately intending to evade [the prohibition]'. See also Ormerod, n 28, p 17 (referring to Lane CJ at p 856). One would agree save that 'deliberately intending' is the same as 'knowingly' and that 'dishonestly and deliberately intending to evade' is the same as an 'intent to defraud'.

${ }^{343}$ OED, n 128 (false) '1a. Of opinions, propositions, doctrines, representations: contrary to what is true, erroneous.' Also 'The etymological sense of L[atin] falsus is 'deceived, mistaken' (of persons), 'erroneous' (of opinions etc). The transition to the active sense 'deceitful' is shown in phrases like falsa fides 'breach of trust, faithfulness' where the sb. has a subjective and an objective sense.' False is not the same as fraudulent Cf. Taxes Management Act 1970, s 20BB (offence if a person 'intentionally falsifies, conceals, destroys or otherwise disposes of, or causes or permits the falsification, concealment, destruction or disposal of, a document which has been required etc'). See also Customs and Excise Management Act 1979, s 168 (counterfeits or falsifies any document etc).

${ }^{344}$ See also D Ormerod, Fraudulent Evasion of Income Tax [2002] Crim LR 3.

${ }^{345}$ The provision was repealed by the Taxation (International and Other Provisions) Act 2010, sch 10(2), para 1.

${ }^{346} R e$ involvement in specified EC Fraud offences see Criminal Justice Act 1993, s 71 (a person in the UK who 'assists in or induces any conduct outside the United Kingdom which involves the commission of a serious offence against the law of another Member State', guilty of an offence).

${ }^{347}$ See similar wording in Customs and Excise legislation, see 26.

348 'Statutory tax' would expressly list the various Taxes Acts, in order to ensure that it does not apply, for example, to other sums owed to the Crown (eg. unpaid rent). It would also not include any common law toll (this comprised a medieval form of local tax arising pursuant to the terms of a charter or letters patent). Common law tolls are now obsolete (or the toll is now a derisory sum). They have been superceded 
(b) statutory customs and excise duty; ${ }^{349}$

(c) court fine or amercement. ${ }^{350}$

3. A person also defrauds the public revenue when a person, with intent to defraud, appropriates any:

(a) sum paid into court (whether held on trust or otherwise). ${ }^{351}$

4. An offence, in section 1 or 2 does not require:

(a) proof of loss to the Crown; or

(b) deception.

5. An offence in section 1 can occur by omission as well as by commission.

\section{An Alternative - Abolition or a Generic Offence?}

Two other issues should be considered:

\section{(a) Abolish Common Law Offence?}

One would assert that the common law offence should be abolished. However, it needs to be replaced with a statutory offence since not all tax, tax credit and customs and excise legislation presently contains wording the same as in $\mathbf{2 6 .}$

- Further, the common law offence is not the same as the statutory provisions in 26. For example, the common law offence does not require: (a) proof of loss; (b) deception. Further, it can occur (c) by omission as well as commission. Also, the legislation referred to in $\mathbf{2 6}$ tends to refer to'knowingly' which is not the same as 'dishonestly;'

- However, it would also not seem appropriate that any new statutory offence be cumulative. ${ }^{352}$ Given this, it is asserted that consideration should be given to amending tax, social security and customs and excise legislation so it also covers (a)-(c) above. Also, by amending reference to 'knowingly' so that it reads 'dishonestly or knowingly'.

If so, then, the common law offence - when statutory - may provide that it does not apply to the legislation referred to in 26. However, the new statutory offence would apply to any taxes, customs and excise and social security acts without such wording.

\section{(b) Combine Tax \& Customs Offences?}

A problem with the current tax and customs and excise wording in $\mathbf{2 6}$ (and, doubtless, with any other similar wording in other tax and customs and excise offences) is that it is not uniform. There are slight variations. For example, the tax wording emphasises 'knowingly' as well as 'fraudulent' whereas the customs and excise wording simply makes reference to an 'intent to defraud'. In fact, it should be the same for all tax and customs and excise legislation. For example, it was (in the first instance) and is (in the other instances) an offence if a person is:

- Income Tax: "knowingly concerned in the fraudulent evasion of tax [income tax] by him or another person'

- $\quad$ VAT. 'knowingly concerned in, or in the taking of steps with a view to, the fraudulent evasion of VAT by him or any other person';

- Tax Credits. 'knowingly concerned in any fraudulent activity undertaken with a view to obtaining payments of a tax credit by him or any other person'.

Thus, it is asserted that Defrauding the Public Revenue could be:

\footnotetext{
by statutory tolls in one or two cases, such as bridge tolls. Since legislation specifies the penalties (which are usually not large) there would seem to be no need to include them in any statutory offence of defrauding the public revenue. For the obsolesence of common law tolls, see GS McBain, Modernising the Monarchy in Legal Terms - Part 4 (2012) KLJ, vol 23, 285-311.

${ }^{349}$ Customs and excise duties would appear to be wholly statutory now. For a case of conspiracy to cheat the public revenue (by evading Customs import duty on goods) see $R v$ Blake (1844) 6 QB 126 (115 ER 49). Per Denman CJ at p 132 'The charge is for conspiracy to procure imported goods, in respect of which duties were payable, to be delivered to the owners without payment.'

350 'Court fines' would refer to any fines which a court ordered a person to pay.

${ }^{351}$ See 29.

${ }^{352}$ Cf. Ormerod, n 28, p 642 'The danger is that the common law offence will be strained, or continually expanded when the statutory offence would suffice.' See also pp 641-3 (relationship to other offences).
} 
'If a person is knowingly concerned in, or in the taking of any steps with a view to, any fraudulent:

(a) evasion of [any statutory tax]; or

(b) activity to obtain the payment of [any statutory tax credit],

by him or any other person'.

As to customs and excise, it is, presently, an offence if a person:

- Customs \& Excise (evasion of duty) 'knowingly acquires possession' of certain goods 'with intent to defraud' Her Majesty 'of any duty payable on the goods or to evade any such prohibition or restriction with respect to the goods;'

- Customs \& Excise (improper importation of goods) 'with intent to defraud Her Majesty of any such duty or to evade any such prohibition or restriction' as mentioned.

Thus, it is asserted that Defrauding the Public Revenue could also be:

'If a person knowingly:

(a) acquires possession of [certain goods]; or

(b) imports [certain (improper) goods]

with intent to defraud the Crown of any duty payable thereon or to evade any such prohibition or restriction with respect to the same.'

If it was also provided that these offences did not require; (a) deception; (b) proof of loss and (c) could be by way of omission as well as commission, then the common law and statutory offences could be combined. Indeed, the basic provision should be that a 'person with intent to defraud' since this is common to all the offences and would cover 'knowingly'. ${ }^{353}$ Thus, it may be time for the common law offence to become a generic offence. This could then apply to all stipulated tax and customs and excise acts as well as to other frauds against the public revenue. This, obviously, would reduce uncertainty and litigation. It would also avoid alternative, or cummulative, offences.

In conclusion, consideration should be given to there being a statutory offence which covers all taxes and customs and excise duties. This would mean abolishing the common law offence of defrauding the revenue and replacing the distinct tax and customs offences (with their subtle variations) with this one generic offence. This should be the 'end game. ${ }^{354}$

\section{Misconduct in a Public or Judicial Office}

A previous article has considered the offence of misconduct in a public or judicial office. It is important that this offence (which, it is asserted, should also, now, be statutory) be dovetailed with the offence of defrauding the public revenue.

- In the case of the former it has been asserted it should not cover financial offences since, otherwise, there is a real danger it will be used as a 'catch all' to cover offences that are caught anyway within the terms of the Theft Acts 1968-78 and other related legislation;

- Further, there is no need for this either. If one considers the caselaw, the cases cited as examples of the former only comprise: (a) Bembridge (1783); (b) Buck \& Hale (1703) ${ }^{355}$ and (c) Llewellyn v Jones (1967). ${ }^{356}$ The first two are now covered by the Theft Act, 1968, s 17. In (c), a county court registrar was charged with (i) 6 counts of misconduct in a public office; (ii) 5 counts of fraudulent conversion; (iii) one count of fraudulent disposal of property; (iv) one count of obtaining credit under false pretences. The offence committed was that he dishonestly appropriate court funds held on trust for two disabled persons (he used the money to pay off a mortgage). Today, one is sceptical whether any charge in (i) should have

\footnotetext{
${ }^{353}$ ie. it is an offence 'if a person: (a) with intent to defraud the Crown, is concerned in, or in the taking of any steps with a view to: (i) the evasion of [any statutory tax] by him or another person; or (ii) any activity to obtain the payment of a tax credit, by him or any other person; or (b) acquires possession of [certain goods] or imports [certain goods], with intent to defraud the Crown of any duty payable thereon or to evade any such prohibition or restriction with respect to the same.'

${ }^{354}$ This may take two stages: (a) making the common law offence statutory (and excluding it where tax and customs and excise legislation otherwise covers the matter); and (b) creating a generic offence, by combining all the statutory offences.

${ }^{355}$ In this case two tax collectors assessed, and rated, some taxpayers at too high a rate. They also omitted to tax some in their books and yet levied the taxes on them and put the money in their own pocket.

356 (1967) 51 Cr App R 204.
} 
been brought since the matter should have been left to the general law, to prevent the offence of misconduct in a public office being used as a catch-all (or to enhance the penalty). However, in any case, since the funds in question comprised Crown money (albeit on trust), one would assert that defrauding the public revenue should also include where a person intends to defraud the same of money paid into court (see 27, point 3);

- If this is not done there is a risk that a person could be alternatively prosecuted for fraud offences under (a) tax or customs and excise laws; (b) misconduct in a public or judicial office; (c) defrauding (cheating) the public revenue; (d) fraud and theft offences under the general law. This is conducive to confusion and litigation. Thus, it is asserted that (b) should not apply when (a), (c) or (d) apply and that (c) should not apply where (a) otherwise expressly covers the matter. Further, (b) and (c) should be statutory.

In conclusion, misconduct in a public office should be dovetailed with any new statutory offence of cheating the public revenue. Further, the former should not cover any financial matters. This should be left to the general law as well as the offence of defrauding the public revenue (where applicable).

\section{Conclusion}

It is important our criminal law be modern and up-to-date as well as intelligible. Unfortunately, much of our criminal law is still very dated and, often, it is virtually intelligible.

- Given this - and to prevent unnecessary confusion and cases -, it would seem imperative that common law offences are now either abolished (where obsolete) or placed in a modern statutory context;

- In the case of the offence of 'Cheating the Public Revenue' this would not seem difficult (or time consuming) once the original nature of the offence is understood. Thus, there should be a statutory offence of 'Defrauding the Public Revenue' based on an 'intent to defraud'. The latter word implicitly contains the concept of 'knowingly' and 'dishonestly' and not just error, oversight etc;

- In time, this offence should be 'merged' with the statutory offences relating to tax and customs and excise evasion. In so doing, this would return to the basic offence as it was at the time of Bracton (c 1240) and before that. That is, it was 'theft' where a person appropriated revenue otherwise due to the Exchequer. ${ }^{357}$

\footnotetext{
${ }^{357}$ In the time of Bracton (c 1240), a person (the accountant, the one required to pay the Crown) had to appear in person at the Exchequer and to give an oath. Thus, to deliberately fail to provide his the tax position to the Exchequer was also perjury (see also Reeves, $\mathrm{n} 65$, vol 2, pp 350, 353). One wonders whether this should not be brought back. That is, that all persons should be required to swear on oath that, "to the best of their knowledge, the tax return (statement) which they provide contains a just and accurate position as to their tax affairs, such that the Revenue will be able to accurately determine the due amount of tax owed.' If a person breached this, they would be liable for perjury, regardless of any other offence. This would also likely close down many a dubious tax avoidance scheme which operates on the basis of the Revenue not fully understanding (or it being too complex for them to understand) the true tax position.
} 


\section{$\underline{\text { Appendix A }}$}

27 Ass pl 171353 13(b) Presentment for unlawfully withholding money levied for an array of archers.

Tarrant $1767 \quad \mathbf{1 6}$ Information against a parish overseer for procuring a child to be 'offloaded' onto another parish, with concommitent cost.

Jones

1777

14

An apprentice unlawful enlisted, defrauding the Crown (via an army paymaster).

Bembridge 1783 13(b) Accountant in the office of the Receiver and Paymaster General of the Forces, deceitfully (ie. corruptly) concealed from his superior his knowledge that certain sums, which should have been inserted into a final account, were omitted.

Robinson

1799

15(a) Highway surveyor (from the Crown Office) converted to his own use gravel dug at the expense of the inhabitants of the parish. Also, he employed, for his private gain and emolument, the labourers and teams of the parishioners which he ought to have employed in repairing the highways.

Bradbury \& 1920 17(a) Delivered false income tax, excess profits duty and super tax Common law Edlin offence upheld.

Rex v J 1931

17(b)

Hudson 1956

False statement relating to income tax. Common law offence upheld.

Mavji

$1987 \quad 21$

Appellant had a statutory duty to make VAT returns and to pay to the Crown the VAT due. Did neither. Offence committed. No further act or omission required to be alleged or proved. Notwithstanding the existence of a statutory offence of fraudulently evading payment of VAT, the common law offence could be charged.

Redford 1988

22

Common law offence available even though statutory offences might be available. Further, omission as well as commission was sufficient to comprise the offence.

Mulligan 1990

23

Income tax exemption and book of vouchers stolen. $\mathrm{M}$ charged with conspiring (with $\mathrm{W}$ ) to cheat the Crown and the public revenue, going equipped to cheat, handling and theft. Submission that the common law offence unknown to the law, was rejected.

Less

199323
Dishonest withholding of PAYE and National Insurance payments. It was held that the common law offence did not necessarily require a false representation by words or conduct. 
Hunt $1994 \mathbf{2 3}$ Appellant appealed against his conviction of conspiring to cheat the Inland Revenue on the basis that loss had to be proved. Appeal dismissed. The common law offence was a conduct offence.

\section{Copyright}

Copyright for this article is retained by the author(s), with first publication rights granted to the journal.

This is an open-access article distributed under the terms and conditions of the Creative Commons Attribution license (http://creativecommons.org/licenses/by/3.0/). 